\title{
The imprint of plants on ecosystem functioning: A data-driven approach
}

\author{
Talie Musavi ${ }^{a, *}$, Miguel D. Mahecha ${ }^{a, b}$, Mirco Migliavacca ${ }^{a}$, Markus Reichstein ${ }^{a, b}$, \\ Martine Janet van de Wegc ${ }^{c}$, Peter M. van Bodegom ${ }^{d}$, Michael Bahn ${ }^{\mathrm{e}}$, Christian Wirth ${ }^{\mathrm{b}, \mathrm{f}}$, \\ Peter B. Reich ${ }^{g, h}$, Franziska Schrodt ${ }^{a, b}$, Jens Kattge ${ }^{a, b}$
}

a Max Planck Institute for Biogeochemistry, 07745 Jena, Germany

' German Centre for Integrative Biodiversity Research (iDiv) Halle-Jena-Leipzig, 04103 Leipzig, Germany

c SIMBIOS, Abertay University of Dundee, Dundee DD1 $1 \mathrm{HG}$, Scotland, UK

IInstitute of Environmental Sciences (CML), University Leiden, 2333CC Leiden, The Netherlands

e Institute of Ecology, University of Innsbruck, 6020 Innsbruck, Austria

${ }^{f}$ Systematic Botany and Functional Biodiversity Research, Institute of Biology, University of Leipzig, 04103 Leipzig, Cermany

8 Department of Forest Resources, University of Minnesota, St Paul, Minnesota 55108, USA

"Hawkesbury Institute for the Environment, University of Western Sydney, Penrith, 2751 New South Wales, Australia

\section{A R T I C L E I N F O}

\section{Article history:}

Received 31 October 2014

Accepted 12 May 2015

Available online 2 July 2015

\section{Keywords:}

Biosphere-atmosphere interactions

Biogeochemical fluxes

Scaling

Ecosystem functional properties

Plant traits

Remote sensing

\begin{abstract}
A B S T R A C T
Terrestrial ecosystems strongly determine the exchange of carbon, water and energy between the biosphere and atmosphere. These exchanges are influenced by environmental conditions (e.g., local meteorology, soils), but generally mediated by organisms. Often, mathematical descriptions of these processes are implemented in terrestrial biosphere models. Model implementations of this kind should be evaluated by empirical analyses of relationships between observed patterns of ecosystem functioning, vegetation structure, plant traits, and environmental conditions. However, the question of how to describe the imprint of plants on ecosystem functioning based on observations has not yet been systematically investigated. One approach might be to identify and quantify functional attributes or responsiveness of ecosystems (often very short-term in nature) that contribute to the long-term (i.e., annual but also seasonal or daily) metrics commonly in use. Here we define these patterns as "ecosystem functional properties", or EFPs. Such as the ecosystem capacity of carbon assimilation or the maximum light use efficiency of an ecosystem. While EFPs should be directly derivable from flux measurements at the ecosystem level, we posit that these inherently include the influence of specific plant traits and their local heterogeneity. We present different options of upscaling in situ measured plant traits to the ecosystem level (ecosystem vegetation properties - EVPs) and provide examples of empirical analyses on plants' imprint on ecosystem functioning by combining in situ measured plant traits and ecosystem flux measurements. Finally, we discuss how recent advances in remote sensing contribute to this framework.
\end{abstract}

(C) 2015 Elsevier B.V. All rights reserved.

\section{Introduction}

The structure and functioning of terrestrial ecosystems are formed by environmental (e.g., climatic and edaphic) constraints, as well as the legacy of ecosystem development. Historical processes such as evolution, migration, and disturbances are encoded in the community structure of biota (i.e., plant or soil organism communities, their horizontal and vertical structure and temporal dynamics). In turn, the biotic structure shapes the biogeochemical functioning of ecosystems, i.e., nutrient turnover, water cycling, and carbon storage potential amongst others (Field et al., 1992; Friend and

\footnotetext{
* Corresponding author. Tel.: +493641576296.
}

Cox 1995; Schlesinger 1997; Chapin et al., 1998). To put it in other words: responses of biogeochemical processes to environmental conditions are modulated by the local properties of organismic communities (Field et al, 1992). The interacting effects of organismic responses and biophysics at the ecosystem level ultimately shape ecosystem feedbacks to the climate system as manifested in the exchange of energy and greenhouse gases and cycling of chemical compounds (Bonan, 2008).

Commonly used terrestrial biosphere models implement biogeochemical and biophysical processes according to our understanding derived, in large part, from plant organ level observations, and use parameters that are often based on observable plant traits. Plant traits are measurable features at the individual organ or organism level such as morphological, anatomical, phys- 


\section{Definitions used throughout the manuscript}

Ecosystem functional property (EFP) Indicators of ecosystem functional state. Quantities that characterize ecosystem processes and responses in an integrated and comparable manner (Reichstein et al. 2014),

Ecosystem vegetation property (EVP) Indicators, characterizing the properties of the vegetation in the context of an ecosystem.

Eddy covariance (EC) A micrometeorological method to measure exchanges of heat, mass, and momentum between a surface and the overlying atmosphere (Baldocchi et al., 2001), based on the covariance between turbulent fluctuations of the vertical wind and the scalar fluctuation, of the quantity of trace gases of interest (Baldocchi et al., 1988; Foken and Wichura, 1996; Aubinet et al., 2000; Baldocchi, 2008).

Ecosystem flux The exchange of matter and energy between an ecosystem and the atmosphere per unit time measured with the eddy covariance technique (Luyssaert et al., 2009; Reshef et al., 2011).

FLUXNET A network of regional networks, which coordinates regional and global analysis of observations from EC tower sites. (http://fluxnet.ornl.gov/).

TRY A network of vegetation scientists, which provides a global archive of plant traits (http://www.try-db. org).

Plant functional type (PFT) Plant functional type is a term that groups plants according to a limited number of plant attributes of life form, phylogeny, or morphology (Box, 1996).

iological or phenological traits (Violle et al., 2007). Measurements of plant traits have frequently been used for model development and parameterization, such as leaf carboxylation capacity $\left(V c_{\max }\right)$, maximum $\mathrm{CO}_{2}$ assimilation rates $\left(A_{\max }\right)$, and nitrogen content per leaf area (e.g., White et al., 2000; Kattge et al., 2009; Goll et al., 2012). However, the representation of plant biodiversity in common terrestrial biosphere models is very limited and rarely goes beyond differentiating ten to fifteen (depending on the model) plant functional types (PFTs). This approach largely ignores variability of characteristics within individual PFTs (but see van Bodegom et al., 2012; Reich et al., 2014; Reichstein et al., 2014). The increasing availability of relevant information on plant traits offers unprecedented opportunities for introducing more detailed functional diversity in global models of the terrestrial biosphere (Brovkin et al., 2012; van Bodegom et al., 2012; Wang et al., 2012; Pavlick et al., 2013; Verheijen et al., 2013). Functional diversity is defined herein as the variability within and among locations of both the trait mean and trait variance due to differences among organs, individuals, or species; or through time. Models that explicitly represent functional diversity will provide even more detailed predictions of plants' imprint on ecosystem processes (Scheiter et al., 2013).

Advancing model structures should be accompanied by developing a sound independent model-benchmarking system (Luo et al., 2012). However, even if the next generation of models integrate trait diversity and their effects on biogeochemical and biogeophysical processes (Reu et al., 2011; Scheiter et al., 2013; Pavlick et al., 2013), we anticipate that the biodiversity feedbacks will be particularly difficult to evaluate. We therefore assume that independent empirical analyses on the linkage of plant traits to emergent ecosystem scale properties will be needed and should remain independent from the model assumptions. Therefore, motivation for data driven, empirical analyses of plant characteristics in combination with ecosystem level exchanges of carbon, water, and energy are twofold.

First, the identification of robust empirically derived biodiversity effects on ecosystem functioning can become valuable for model benchmarking, and allow for testing whether the assumed relationships between plant traits and ecosystem functions in models are comparable to those observed (e.g., Luo et al., 2012). Second, it is important to identify key characteristics of plants that influence ecosystem functions, which might not have been considered yet. These are beneficial, both to facilitate a better understanding of the sensitivity of ecosystem exchanges of matter and energy to long-term environmental changes (including feedbacks to vegetation, soil and climate), while also being applicable to quantifying and understanding ecosystem services that are linked to ecosystem functions and processes (de Bello et al., 2010). Soil biota also has an important role in ecosystem processes (Neher 1999; Wall and Moore, 1999). However, information about soil biota is difficult to access via in situ measurements and hardly available via remote sensing (hereafter RS, but see Fisher et al., submitted), hence here we focus on plants.

The topic of how plants influence ecosystem functioning and how to predict ecosystem functions from 'effect traits' (sensu Lavorel and Garnier, 2002) has been discussed for several decades in the literature and is sometimes considered a "holy grail" in ecology (Grime 1979; Southwood 1988; Chapin et al., 2000; Lavorel and Garnier, 2002). Conceptual studies in this direction usually emphasize the relationships existing between plant traits and ecosystem processes or functions, but often are not explicit about the ecosystem functions and processes, nor how they could be estimated from ecosystem level observations and ultimately linked with plant traits. Moreover, in these literatures, the ecosystem functions are heavily dominated by snap-shot or annually integrated measurements of state variables or component processes, such as net primary production (NPP), leaf area index (LAI), or standing biomass, which are integrated over numerous component processes (see Hooper et al., 2005). Standing biomass, as an example, is the result of the physiological balance of the fluxes of photosynthesis and respiration, carbon allocation, organ-level growth and mortality, and biotic and abiotic losses, such as herbivory and storm breakage respectively. Trait influences on these component processes - typically fluxes of matter and energy - may be strong, but may remain hidden when relating traits to only state variables. A group of plant traits might influence changes of standing biomass, but it is also important to understand their influence on the processes resulting in the standing biomass. To overcome such limitations, we propose to link plant traits with essential features of ecosystem functioning, which can be derived from observations of ecosystem energy and matter fluxes - the direct result of relevant ecosystem processes like e.g., photosynthesis, respiration, or evapotranspiration.

In this conceptual paper, we highlight opportunities - so far not fully explored in ecology - arising by consolidating information on plant species characteristics (in situ and remotely sensed) and ecosystem fluxes at local to global scale. First, we introduce a conceptual framework that defines ecosystem functional properties (EFPs) as variables of ecosystem functioning that include physiological processes and their responses to the environment (Section 2). Then, we introduce top-down (Section 3.1) and bottom-up (Section 3.2 and 3.3) scaling approaches to match the temporal and spatial scales of observed plant traits and EFPs. In the final part, we will discuss how remotely sensed information can be effectively used in this context (Section 4). Overall, we will propose pathways to empirically analyze the intrinsic biotic controls of terrestrial ecosystems and 


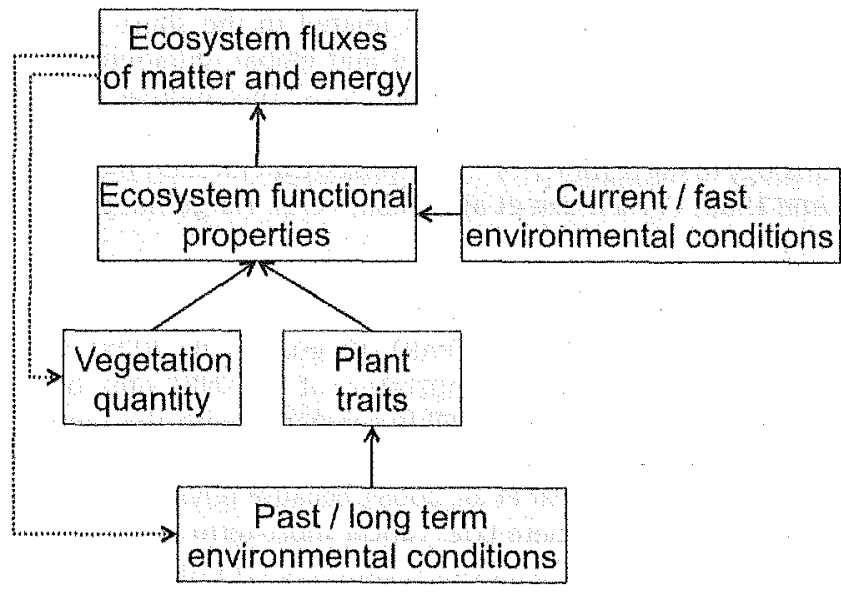

Fig. 1. Concept for mapping plant traits via ecosystem functional properties onto ecosystem fluxes, separating slow and fast changing environmental conditions. The concept is based on the hypothesis that plant traits adapt to long term, slowly changing environmental conditions, like seasonal or annual mean or extreme conditions. Together with vegetation quantity (e.g., biomass or LAI) plant traits determine ecosystem functional properties (EFPs). Fast changing environmental conditions, like diurnal or seasonal variation, determine ecosystem fluxes of matter and energy via the EFPs. Ecosystem fluxes determine changes of vegetation quantity, and may feedback on long term environmental conditions. We propose that the concept can be generalized, replacing vegetation quantity and plant traits by organisms quantity and organisms traits.

its effect on ecosystem functioning. We expect these new pathways to contribute to our understanding of which plant traits or plant trait combinations control spatiotemporal variations of functions occurring at the ecosystem scale, in interaction with climate and environmental factors.

\section{The imprint of plants on ecosystem functioning: a conceptual basis for a data driven approach}

Ecosystem functional properties (hereafter EFPs) should capture process attributes or responsiveness of ecosystems (often very short-term in nature) that contribute to the long-term (i.e., annual but also seasonal or daily) metrics commonly in use. Reichstein et al. (2014) defined EFPs "as quantities that characterize ecosystem processes and responses in an integrated and comparable manner" (page 13698). Thus EFPs are both conceptual in nature and quantifiable from ecosystem processes, and are analogous to ecophysiological leaf-level characteristics or relate to physical and ecohydrological characteristics important for land surface-atmosphere interactions (Reichstein et al., 2014). Following this definition, EFPs should provide relevant process characteristics, for instance maximum flux rate, flux rates under standardized environmental conditions (base rate), or the slope of changing rates given changes in environmental drivers (e.g., light response or temperature responses; sensitivities), or the fraction of such characteristics. EFPs can consequently be used to characterize variations in key processes, like photosynthesis, respiration, or evapotranspiration, or their relationship, like water use efficiency of photosynthesis (the amount of carbon gained by water transpired). As they characterize specific ecosystem processes, EFPs can be derived from observable ecosystem fluxes (the observable components of the processes), from the quantity (e.g., abundance) and characteristics (plant traits) of the organisms (the operators of the processes), or potentially inferred via RS at ecosystem level (Fig. 1). In general terms, EFPs can be understood as empirically derived equivalents at the ecosystem scale to parameters (at ecosystem scale) in terrestrial biosphere models. In relation to aggregated plant trait observations, EFPs thus enable us to examine the influ-

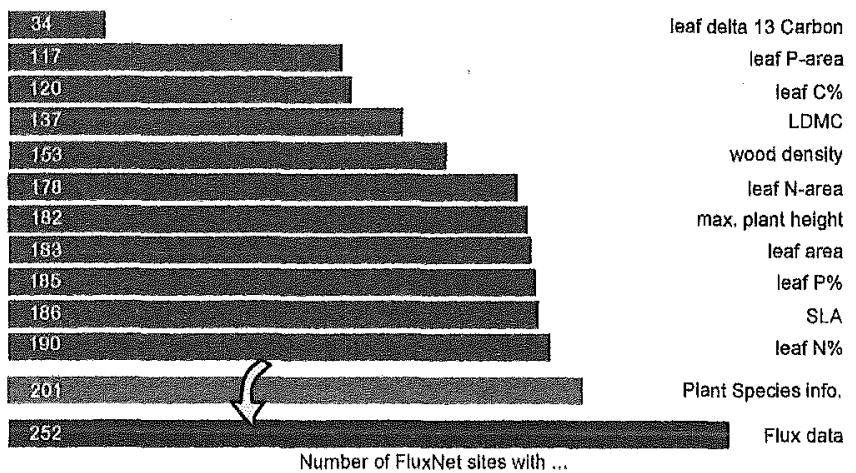

Fig. 2. The number of FLUXNET sites with traits in TRY. Bottom: Number of sites with available flux data in the FLUXNET La Thuile database. The second bar provides the number of sites with information of dominant plant species available in the FLUXNET ancillary database. The arrow indicates that we could use plant traits at the sites only by knowing which species exist at these sites. The remaining numbers on each bar are showing the number of FLUXNET sites for which the plant trait on the left side is available from TRY database for at least one of the site-species. (Traits from Table 1 are shown here)

ence of biotic and abiotic controls on the various components of the processes (Fig. 1).

So far, empirical analyses of the relationships between plant traits and ecosystem functions have been primarily limited to ecosystems or regional scales (Pierce et al., 1994; Kergoat et al., 2008; Ollinger et al., 2008; Cleveland et al., 2011; Reich 2012), or to whatever is available from the literature (e.g., Green et al., 2003). This is, in part, due to limited measures in biomes, but also because the relevant data (e.g., plant traits and ecosystem level fluxes) were not always measured simultaneously and have largely not been curated via central repositories. Nowadays, more data for primary ecosystem functions and organism traits are becoming available through RS data and initiatives like FLUXNET (the global network of ecosystem level observations of carbon, water, and energy fluxes on terrestrial ecosystems, Baldocchi, 2008) and TRY (a global archive of plant traits, Kattge et al., 2011). A first intersection of the plant species data from FLUXNET and TRY shows that, for more than 100 sites belonging to FLUXNET, we can gather information on a specific plant trait (e.g., specific leaf area, SLA) of the dominant species at the sites from TRY (Fig. 2). Moreover, the data reported in FLUXNET and TRY cover a variety of climatic conditions, as shown Fig. 3, which makes these empirical analyses possible at a global scale.

Ground-based measurements of plant traits are commonly conducted in ecological studies, but are usually limited in space and in time because of resource constraints (i.e., laborious and time consuming measurements). Moreover, plant traits are usually measured at the leaf or plant level, so in order for them to represent the vegetation of an ecosystem, they need to be upscaled to ecosystem vegetation properties (hereafter referred to as EVP). Here we introduce potential upscaling schemes for in situ measured plant traits to provide the information about biotic controls corresponding to EFPs (see Section 3.2). The developments in the field of RS over the last few decades allows us to retrieve plant traits, which in most cases are integrated at the ecosystem level (EVP) and in some cases continuous in time (Homolová et al., 2013). This is particularly important where the temporal variability of plant traits is relevant. In addition EFPs can as well be retrieved from RS (see Section 4).

\section{Matching scales}

\subsection{Top-down}

One of the challenges of the proposed methodology is that ecosystem fluxes measured with eddy covariance techniques are 


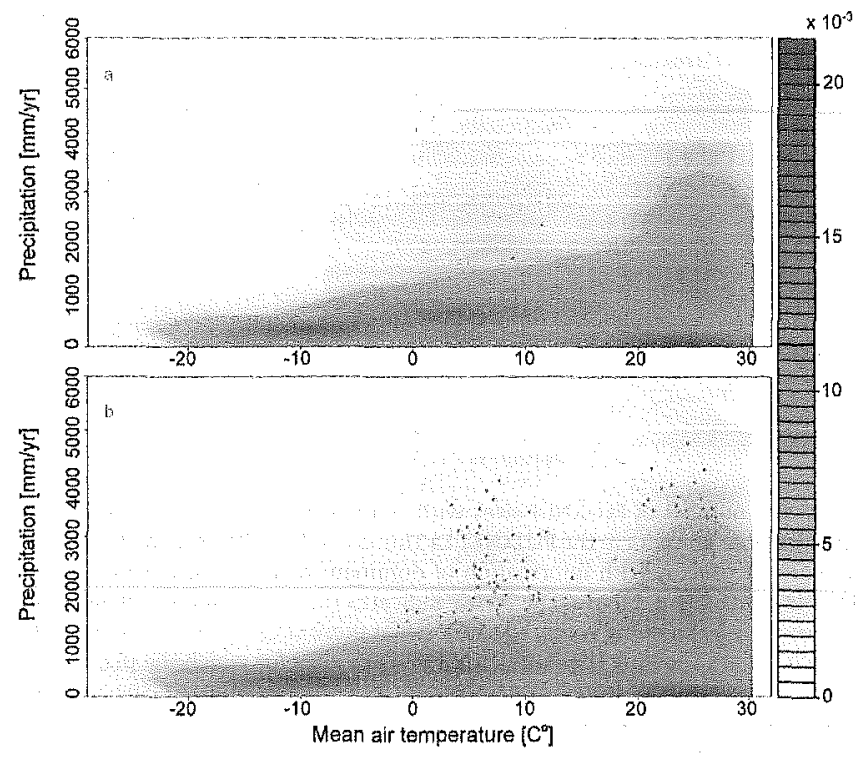

Fig. 3. The distribution of (a) FLUXNET sites, (b) measurement locations from TRY (of various plant traits) in climate space spanned by mean annual temperature and mean annual precipitation. Kernel density estimation was used to show the density of land surface pixels at $0.5^{\circ} \times 0.5^{\circ}$ resolution for the two variables.

not directly comparable with plant traits because they do not vary at the same time scale. To grasp the relationship between plant traits, fluxes, environmental drivers (climate) and soil pools we need to carefully consider the time-scale.

While many plant traits (e.g., leaf mass per leaf area (LMA), gram leaf nitrogen to 100 gram leaf mass (\%N)) typically vary mostly at weekly, seasonal, or longer time scales (Ma et al., 2010), ecosystem fluxes measure short-term responses $(<1 \mathrm{~h})$ but respond to meteorological and environmental conditions at time scales ranging from minutes to seasonal, interannual, and longer and can be integrated at those time scales (Richardson et al., 2007; Stoy et al., 2009). Meteorological drivers such as temperature, precipitation, solar radiation, and snow-cover explain a substantial part of the temporal (in particular daily to seasonal) and spatial variability of observed fluxes (e.g., Dunn et al., 2007; Urbanski et al., 2007). On longer time scales (seasonal, annual) fluxes might lag behind the meteorological factors (Stoy et al., 2009; see also Ogle et al., 2015 for memory effect in ecosystem processes) and for time scales longer than two weeks, fluxes of net ecosystem exchange (NEE) and gross primary production (GPP) are relatively less variable than the meteorological factors (Stoy et al., 2009). This has been attributed to the fact that fluxes are processed by plants, with plant traits changing on longer time scales (e.g. Ordoñez et al., 2009; van Ommen Kloeke et al., 2012; Verheijen et al., 2013). At seasonal and inter-annual scales, it therefore becomes more complicated to attribute multi-scale variability in ecosystem-atmosphere fluxes to hydrometeorological conditions only (Mahecha et al., 2007, 2010; Stoy et al., 2009; Reich, 2010). Thus, in addition to the dominant control of plants and pools on spatial variability of fluxes (e.g., between flux tower variability, e.g., Reichstein et al., 2003), they can possibly also influence the temporal variability of fluxes.

While fluxes of physiological properties such as NEE, GPP, ecosystem respiration, or evapotranspiration are measured with eddy covariance techniques and are readily available in half-hourly time scales, we can use them to derive EFPs that vary over longer time scales (Reichstein et al., 2014), comparable to plant traits. Proposed EFPs in Table 1 can be considered as an integrator of ecosystem functioning less variable in time than the fluxes themselves. By using the concept of EFPs, it is possible to eliminate the high temporal flux variations related to the short term climate variability (e.g., temperature and global radiation) and to standardize for environmental conditions. This approach to control for short-term variation of environmental conditions would be in analogy to suggestions for standardized trait measurements (e.g., Grime 1988; Cornelissen et al., 2003a; Perez-Harguindeguy et al., 2013).

An example for an EFP is optimum light use efficiency (LUE) derived from GPP and normalized by the fraction of absorbed photosynthetic active radiation (fPAR) (Kergoat et al., 2008). LUE is correlated to mean annual temperature at FLUXNET sites, but the correlation fades when this EFP is compared with the temperature corresponding to the time when the GPP flux was retained to compute LUE (Kergoat et al., 2008), because physiological characteristics of the EFP (here LUE) cancel short-term environmental variability. This kind of behavior is expected for other EFPs as well (Table 1). Therefore, EFPs provide empirical estimates of long-term changes of ecosystem functional states, and allow the link with plant traits and the comparison across sites.

Another example for an EFP is the photosynthetic capacity of an ecosystem, which is the potential maximum photosynthesis of the ecosystem over a given period. We suggest the use of GPP1000, which is the GPP or assimilated $\mathrm{CO}_{2}$ of the ecosystem at $1000 \mathrm{~W} / \mathrm{m}^{2}$ of global incoming radiation ( $\mathrm{Rg}$ ) (e.g., Ruimy et al., 1995; Falge et al., 2001). GPP1000 can be derived by fitting non-rectangular hyperbolic light response curves (e.g., Gilmanov et al., 2003) using half-hourly GPP values and $\mathrm{Rg}$ data. Quantified on an annual basis (i.e., 90th percentile of the GPP1000 - to exclude outliers), this EFP characterizes the photosynthetic capacity of an ecosystem (comparable to $A_{\max }$ at leaf scale), which typically occurs at the peak of the growing season, with favorable temperatures and the absence of severe water stress, while it ignores the diurnal and seasonal variability of the fluxes related to irradiance and other environmental conditions. It enables analyses of the inter-annual variability of the photosynthetic capacity and facilitates comparisons across sites. GPP1000 can as well be characterized at shorter time scales, e.g., seasonally, which would then allow monitoring seasonal variation of the ecosystem functional state. However, the seasonal variation of environmental properties - temperatures may be unfavorable, water may be limiting - complicates these analyses.

A third example is water use efficiency (WUE, the ratio between GPP and evapotranspiration) that can be considered as an EFP that links carbon and water cycling. However, WUE instantaneously declines with water vapor pressure deficit (VPD) in the atmosphere; therefore inherent or intrinsic WUE - standardized for VPD - would be a more appropriate EFP (e.g., Beer et al., 2009). But still the exact form of the influence of VPD remains unclear, because VPD influences leaf parameters such as stomatal conductance (Mott and Parkhurst, 1991; Buckley, 2005; Shope et al., 2008) and photosynthetic carbon uptake (Shirke and Pathre, 2004), differently.

We have provided examples of how EFPs can be derived from observed ecosystem fluxes to provide empirical estimates of ecosystem functional states. EFPs facilitate monitoring of seasonal to long-term changes of ecosystem functional states and allow comparisons across sites. EFPs provide the opportunity to link ecosystem functional states to information of the state of the biota, e.g., via plant traits. However, we also point out that one has to critically examine whether an EFP is indeed independent of short-term environmental fluctuations. In Table 1 we provide further examples of EFPs and from which data streams they can be derived.

In the following section we introduce in situ plant trait measurements, and describe how they can be used to derive vegetation properties at the ecosystem level (EVPs) and be directly comparable to EFPs. 
Table 1

List of possible ecosystem functional properties (EFPs) that can be derived from eddy covariance fluxes, with related plant traits and stand characteristics that can be potentially used for deriving the EVPs.

\begin{tabular}{|c|c|c|c|}
\hline Processes & Ecosystem functional properties (EFPs) & Description & Plant traits/stand characteristics \\
\hline \multirow[t]{5}{*}{ Photosynthesis } & $\begin{array}{l}\text { Ecosystem photosynthetic capacity } \\
\left(\mathrm{GPP} 1000_{\text {max }}\right)\end{array}$ & $\begin{array}{l}\text { Maximum ecosystem photosynthesis (e.g., } \\
\text { GPP) standardized for light saturation, e.g., at } \\
\text { light intensity of } 1000 \mathrm{~W} / \mathrm{m} 2 \text { (see Falge et al, } \\
\text { 2001; Gilmanov et al., 2003). }\end{array}$ & $\begin{array}{l}\text { Leaf photosynthetic capacity (Amax; } V_{c_{\max }} \text { ); } \\
\text { leaf nitrogen content per leaf area or dry mass } \\
\left(\mathrm{N}_{\text {leaf }}\right) \text {; leaf mass per area (LMA); } \mathrm{N}: \mathrm{P} \text { ratios } \\
\text { LAI; Species abundance }\end{array}$ \\
\hline & Potential light use efficiency ( LUE $_{\text {max }}$ ) & $\begin{array}{l}\text { Maximum ratio between GPP and absorbed } \\
\text { photosynthetic active radiation (APAR) at } \\
\text { growing season (see Monteith, 1972; Kergoat } \\
\text { et al., 2008). }\end{array}$ & $\begin{array}{l}A_{\max } ; V \mathcal{C}_{\text {max }} ; N_{\text {leaf }} ; \mathrm{LMA} ; \text { plant height; leaf size; } \\
\mathrm{N}: \mathrm{P} \text { ratios } \\
\text { LAI; Species abundance; Canopy structure }\end{array}$ \\
\hline & Nitrogen use efficiency (NUE) & $\begin{array}{l}\text { Maximum GPP1000 divided by leaf nitrogen } \\
\text { content }\end{array}$ & $\begin{array}{l}A_{\text {nax }} ; V_{c_{\text {max }}} ; N_{\text {leaf }} \text { LMA; } N_{\text {plant }} ; \text { wood density; } \\
\mathrm{N}: P \text { ratios } \\
\text { LAl; Biomass; Species abundance }\end{array}$ \\
\hline & Normalized GPP* & $\begin{array}{l}\mathrm{GPP}^{*}=\mathrm{GPP}_{\max } \frac{\mathrm{PPAR}}{\operatorname{PPR}} \frac{\cos (\theta=0)}{\cos (\theta s)} \text { Kergoat et al. } \\
(2008)\end{array}$ & $\begin{array}{l}A_{\text {max }} ; V_{c_{\text {max }}} ; N_{\text {leaf }} ; \text { LMA; } N: P \text { ratios } \\
\text { LAl; Biomass; Species abundance }\end{array}$ \\
\hline & Carbon use efficiency (CUE) & $\begin{array}{l}\text { 1) Biomass production divided by GPP } \\
\text { 2) NPP to GPP ratio (Delucia et al., 2007). } \\
\text { 3) 1-Rb/GPP (Mahecha et al., 2010). }\end{array}$ & $\begin{array}{l}A_{\max } ; V_{c_{\max }} ; N_{\text {lear }}, L M A ; \text { wood density } \\
\text { LAI; Biomass; Species abundance }\end{array}$ \\
\hline Respiration & $\begin{array}{l}\text { Basal ecosystem respiration (Rb): } \\
\text { 1) Rb at day of Max GPP } 1000 \\
\text { 2) Median of seasonal } \mathrm{Rb} \\
\text { 3) Maximum seasonal } \mathrm{Rb} \\
\text { Sensitivity of } \mathrm{Rb} \text { to GPP (Rb/GPP) }\end{array}$ & $\begin{array}{l}\text { Maximum or median of ecosystem respiration } \\
\left.\left(R_{\text {eco }}\right) \text { at a reference temperature ( } 15 \mathrm{C}\right) \text { and at } \\
\text { the time period of no water limitations (Lloyd } \\
\text { and Taylor, } 1994 \text {; Reichstein and Beer, } 2008 \text { ). } \\
\text { Slope of the relationship between Rb and GPP } \\
\text { Mahecha et al. (2010) }\end{array}$ & $\begin{array}{l}N_{\text {leaf }} ; \text { LMA; LDMC; RDMC; wood density } \\
\text { LAI; Biomass (above and belowground) } \\
N_{\text {leaf }} \text { LMA; LDMC; RDMC; wood density } \\
\text { LAI; Biomass (above and belowground) }\end{array}$ \\
\hline \multirow[t]{3}{*}{ Evapotranspiration } & $\begin{array}{l}\text { Maximum ecosystem evapotranspiration } \\
\left(\mathrm{ET}_{\max }\right)\end{array}$ & Maximum of the seasonal ET measured & $\begin{array}{l}\text { Maximum stomatal conductance }\left(\mathrm{gs}_{\max }\right) \\
\text { sapwood area; wood density } \\
\text { LAl; Tree diameter at breast height (DBH) }\end{array}$ \\
\hline & $\begin{array}{l}\text { Inherent water use efficiency } \\
\left(\text { WUE }_{j_{n}}\right)\end{array}$ & $\begin{array}{l}\text { Slope of the relationship between GPP*VPD } \\
\text { and ET Beer et al. (2009) }\end{array}$ & $\begin{array}{l}\mathrm{gs}_{\max } ; N_{\text {leaf }} ; \text { LMA; sapwood area; Amax/gs, } \\
\text { d13C } \\
\text { LAI }\end{array}$ \\
\hline & $\begin{array}{l}\text { Intrinsic water use efficiency } \\
\left(W^{*}\right)^{*} \text { ) }\end{array}$ & $\begin{array}{l}\text { Seasonal GPP divided by surface conductance } \\
\text { (Gs) } \\
\text { GPP/Gs Beer et al. (2009) }\end{array}$ & $\begin{array}{l}\mathrm{gs}_{\text {max }} ; N_{\text {leaf }} ; \text { LMA; sapwood area; Amax/gs; } \\
\text { d13C } \\
\text { LAI }\end{array}$ \\
\hline \multirow[t]{2}{*}{ Biophysical properties } & Energy use efficency & $\begin{array}{l}\mathrm{GPP}_{1000} /(\mathrm{LE}+\mathrm{H}) \text { at the peak of the growing } \\
\text { season or } 90 \text { th percentile GPP/(LE }+\mathrm{H}) \text { at the } \\
\text { peak of the growing season See also Reichstein } \\
\text { et al. (2014) }\end{array}$ & $\begin{array}{l}A_{\max } ; V_{c_{\max }} ; N_{\text {leaf }} ; \text { LMA; } N_{\text {plant }} ; \text { wood density; } \\
\text { gs }_{\max } \\
\text { LAl; Canopy structure: Biomass }\end{array}$ \\
\hline & Minimum seasonal Albedo & $\begin{array}{l}\text { Albedo at the peak of the growing season } \\
\text { Cescatti et al. (2012) }\end{array}$ & $\begin{array}{l}\text { Leaf morphology (shape and size); } N_{\text {leaf }} \\
\text { LAI }\end{array}$ \\
\hline
\end{tabular}

\subsection{Upscaling of in situ measured traits}

Plant traits are traditionally measured in situ and more recently also sensed remotely. In situ measurements of plant traits are performed on plant or plant organ level and need to be upscaled to the ecosystem level (EVPs) to correspond to EFPs (Fig. 4). Thus far, upscaling of plant traits to canopy or ecosystem level has been done mainly by weighting traits by abundance of species, allometry, or biomass (e.g., Garnier et al., 2004). These approaches make sense if the effects of the traits of individual plants are additive, like using the number of individuals to upscale individual biomass to community biomass (Violle et al., 2007). This strategy is also useful for upscaling plant traits such as traits based on concentration e.g., grams of nitrogen or phosphorous per leaf mass. But the functionality of traits does not always scale with the quantity (e.g., abundance) of organism. For example, while photosynthesis scales with the nitrogen content of leaves (Givnish, 1986), it also depends on the position of the leaves (or organ) in the canopy, which determines the ability of the leaf to capture light. Plant productivity per unit nutrient in the whole biomass is another example for the relevance of vegetation structure: it decreases with increasing total biomass due to shading within the canopy and allocation of nitrogen to photosynthetically inactive tissues (Kerkhoff and Enquist, 2006).

An alternative upscaling approach accounting for light absorption along the canopy employs involving LAI and plant height:

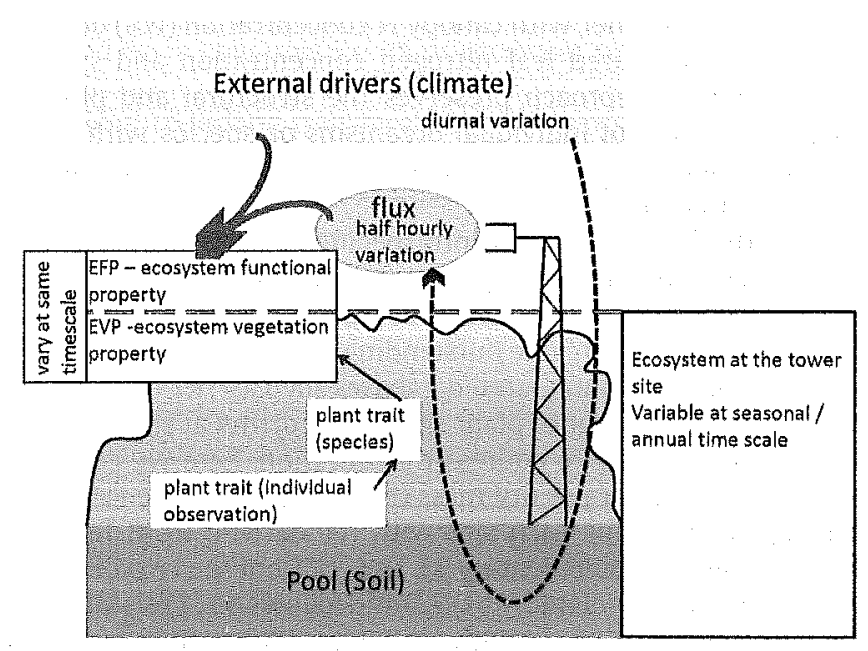

Fig. 4. Top-down and bottom up approaches to determine flux-based ecosystem functional properties (EFP) and trait-based ecosystem vegetation properties (EVPS). To link plant traits measured at the level of individual plants to EFPs, one first needs to upscale plant traits to ecosystem level.

assuming leaves at the top of the canopy contribute most to $\mathrm{CO}_{2}$ assimilation as they receive most of the radiation (Field and Mooney, 1986). Therefore, a canopy strata-weighted measure is needed, as the comparatively larger contribution of species located 
towards the top of a canopy for carbon fixation or GPP needs to be accounted for. To include this strata-weighting when upscaling from plant to EVP, we propose to first weigh each species by its respective abundance plus the amount of radiation it receives using its relative height, thus discriminating for over/understory species. We use the Lambert-Beer law of extinction and implement the relative height (from 0 to 1 ) of the species:

$W_{S}=A_{S} \times e^{k\left(1-H_{s}\right)}$ for $s=1,2,3, \ldots, n$

where $W_{S}$ is the relative contribution (weight) of each species to the ecosystem trait, $A_{S}$ is the abundance of the species, $H_{S}$ is the relative height of the species, and $k$ is the light extinction coefficient (Jones, 2014).

Given a number $n$ of species in the ecosystem the value of the upscaled trait to ecosystem level (EVP) is computed as follow:

$\mathrm{EVP}=\mathrm{LAI} \times \Sigma_{S=1}^{n}$ Trait $_{S} \times W_{S}$

where LAI corresponds to the LAI of the ecosystem $\left(\mathrm{m}^{2}\right.$ leaf $/ \mathrm{m}^{2}$

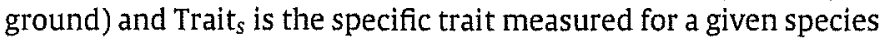
measured on leaf area basis. The resulting EVP will be at ecosystem scale and the unit will be per ground area. For example, by using Eqs. (1) and (2) it is possible to scale-up the nitrogen $(N)$ content per leaf area $\left(\mathrm{g} / \mathrm{m}^{2}\right)$ to the $\mathrm{N}$ concentration per ground area, the latter being the EVP, which can then be linked to the corresponding EFPs such as GPP1000 or LUE.

The advantage of this method of weighting traits by vertical structure rather by abundance is that it considers vegetation structure (i.e., plant height and LAI) and therefore incorporates the differences of plant species contributions to processes like ecosystem photosynthesis. Compared to abundance weighted means, a disadvantage of this more explicit approach is the need for additional data and that the additional parameters add more uncertainty.

Plant traits and the amount of vegetation, e.g., LAI or plant biomass, bear complementary information to explain ecosystem functioning (Fig. 3). As such, RS data of vegetation have the potential to benefit the framework. For example Reich (2012) showed that aboveground net primary production was well explained by LAl (which can increasingly be retrieved from RS, although it was not in that study) together with canopy $\mathrm{N}$ concentration ( $\mathrm{N} \%$ ) derived from in situ measured leaf nitrogen concentration and species abundance. This approach preserves the structural and physiological differences of individual organisms or species within the ecosystem, and facilitates an analysis of the biodiversity imprint on ecosystem function.

While there is considerable intraspecific variation of plant traits, across large geographic scales, most of the trait variations are observed between species (Kattge et al., 2011; Violle et al., 2012; Albert, 2015). Therefore one outstanding question is whether data available from large integrated databases such as TRY can be used to characterize the trait of plant species occurring at specific sites (e.g., FLUXNET sites). To address this question, here we compare leaf nitrogen content per dry mass (N\%) reported in the FLUXNET ancillary database for each site with $\mathrm{N} \%$ derived from the TRY database (Fig. 5, Supplementary 1). The N\% from the two different sources is highly correlated $(r=0.72)$ and follows a $1: 1$ relationship. This result is in agreement with growing evidence from independent results of similar studies (e.g., Cordlandwehr et al., 2013; Kazakou et al., 2014). This is encouraging, as it makes it possible to use general plant trait databases for a first inspection on trait influences on EFPs.

We furthermore tested if the correlation between an EFP derived from ecosystem fluxes and an EVP obtained by using information from TRY is similar to the one derived from traits measured at the sites. To this end, we provide an example correlating optimum daily LUE and canopy normalized GPP (reported as gross

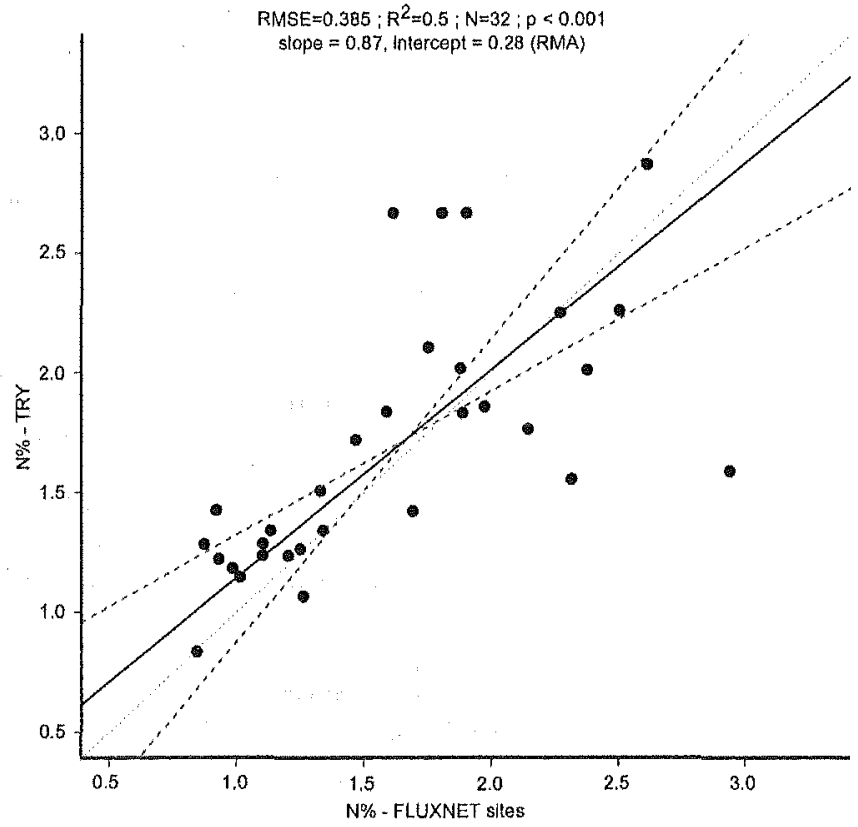

Fig. 5. Comparison of leaf nitrogen content per leaf dry mass (N\%) reported in the FLUXNET ancillary database (N\% - FLUXNET sites) and up-scaled using species mean trait values from the TRY database and species abundance from the FLUXNET ancillary database (N\% - TRY). In case of more than one value reported in the FLUXNET ancillary database, we used the average N\%. N\% - TRY is based on species averaged values from the TRY database that were used for species at the sites. This values are then weighted by the abundance of the species (Table 1 in Supplementary). Slope and intercept were estimated by a reduced major axis (RMA) regression ( $R=0.72$ ).

ecosystem exchange, GEE in Kergoat et al., 2008, see Table 1) with canopy N\%. LUE and canopy normalized GPP are derived from eddy covariance fluxes from FLUXNET sites, including different PFTs. First we collected species composition and abundance at these sites from FLUXNET ancillary database and compared it with information from the literature (Supplementary 1). Then, for every species at the site, species-averaged N\% was derived from TRY. Then canopy $N \%$ was estimated by abundance weighted mean of N\% at each site. Canopy N\% as the EVPs of the sites were then compared to the two EFPs (LUE and canopy normalized GPP). The results reported in Fig. 6 for LUE and canopy normalized GPP are comparable to the ones reported in Kergoat et al. (2008), indicating that is possible to use the species-averaged information reported in TRY to predict EFPs derived from specific sites. The results of Fig. 6 are even stronger considering that no filters based on climate or environmental conditions were applied to derive the average N\% for each species. From Figs. 5 and 6, we conclude that strong patterns of plants' imprint on ecosystem function are likely similarly represented when using trait data from global databases.

\subsection{Spatial extrapolation of in situ measured traits}

Upscaling plant traits to continental or global scale will provide the possibility to study them directly in relation to remote sensed EFPs (see Section 4) available on global scales and EFPs derived from fluxes that are upscaled to global maps (Jung et al., 2011). One option to upscale plant traits measured in situ to global scales is to link the trait data with species distribution maps. One application of this approach produced trait maps across North and South America (Swenson et al, 2012). However, this technique faces two major issues: the heavily reliance on high quality species distribution data, which is not available for most of the world, and the issues related to species distribution models (SDM). For 

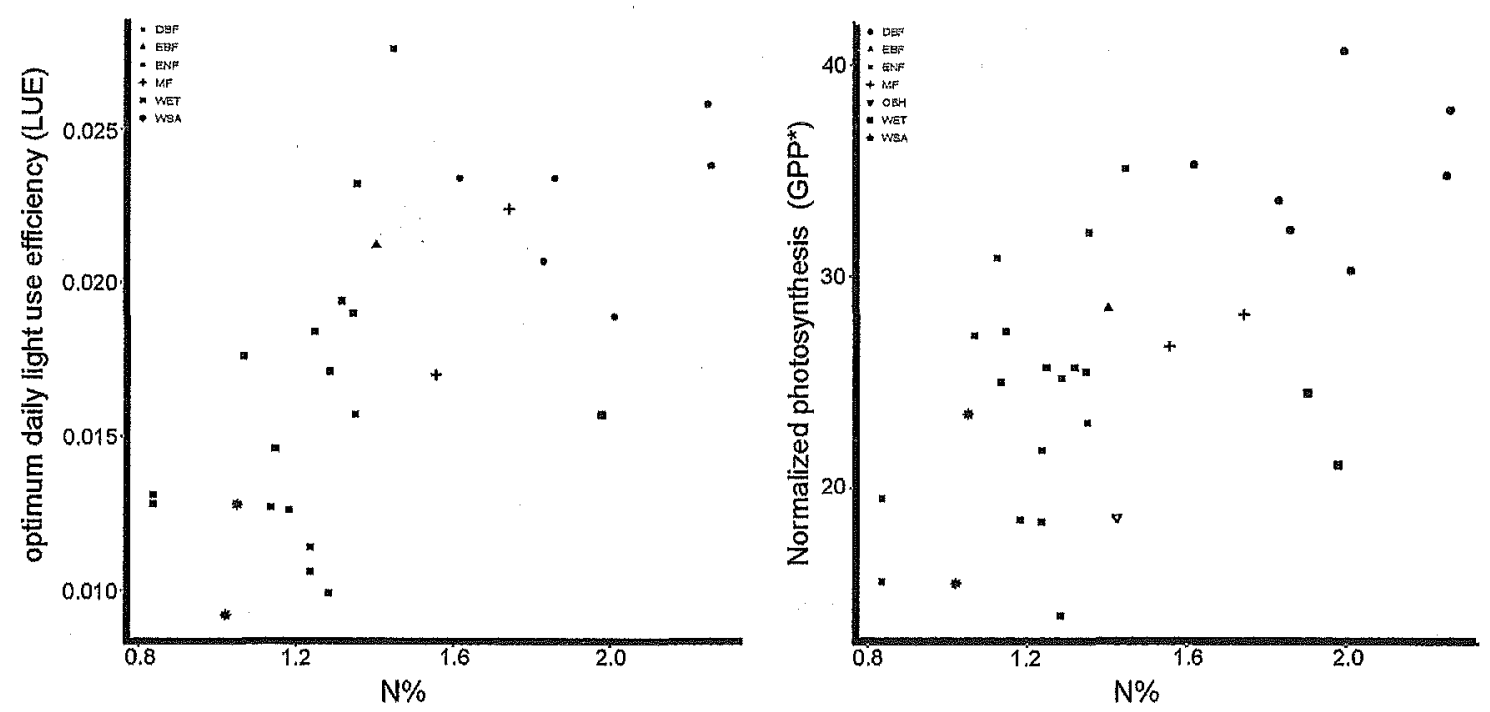

Fig. 6. Optimum daily light-use-efficiency (LUE, mol/mol) and canopy normalized photosynthesis (GPP*, $\mu \mathrm{mols}^{-1} \mathrm{~m}^{-2}$ ) versus leaf nitrogen content per dry mass ( $\mathrm{N}$, \%). LUE and GPP* are reported by Kergoat et al. (2008) for a range of eddy covariance sites with different dominant plant functional types (see labels). Leaf nitrogen content $(\mathrm{N})$ is based on abundance weighted species mean trait values from the TRY database and species abundance from the FLUXNET ancillary database. The variance explained by N\% are $R^{2}=0.41(n=28, p<0.001$, intercept $=0.005 \pm 0.003$, slope $=0.01 \pm 0.002)$ and $R^{2}=0.38(n=32, p<0.001$, intercept $=10.3 \pm 3.7$, slope $=11.1 \pm 2.5)$ for $\mathrm{LUE}$ and $\mathrm{GPP}$, respectively.

example, Henderson et al. (2014) tested the effect of using single species or multivariate modeling approaches on species distributions and found that the multivariate approach outperformed the single species approach by a large margin. The second issue is the assumption that species distributions are, on the one hand, in equilibrium with the environment of the respective organisms and that the traits, which are linked with species distribution data, on the other hand, reflect the whole of the species' trait spectrum. Trait values are known to be highly variable depending on the environmental conditions (Niinemets et al., 2015) with e.g., "tree-like" plant species reaching a much higher maximal height in warm, moist climates, than in cold and dry climates where they get a more "shrub-like" appearance with associated traits. However, as we have shown above, across PFTs and across large environmental gradients, the impact of intra-specific trait variability seems to be dominated by species turnover (Fig. 5, Cordlandwehr et al., 2013; Kazakou et al., 2014).

Another approach to avoid the use of species distribution data is to take advantage of the correlation between traits and environmental conditions and take the direct way. This is illustrated by van Bodegom et al. (2014) who produced global maps of some key traits using trait-environment relationships derived from linking climate and soil variables with community weighted mean trait values.

If a sufficient amount of in situ measured trait data is available, a third approach would be using interpolation techniques, for example Kriging or Gaussian process regression - an interpolation technique where Gaussian processes are taking into account prior covariance (e.g., trait-environment relationships) to model interpolated values. So far, this technique has been mainly applied in geosciences but rarely within macroecology (but see HernandezStefanoni and Ponce-Hernandez, 2006; Henderson et al., 2014 for some examples).

\section{Remote sensing of plant traits and EFPs}

As discussed in Section 3 RS observations provide information about vegetation structural components, like LAI or vegetation biomass. In addition, RS observations in the visible to nearinfrared region of the electromagnetic spectrum have great utility to gather information about plant traits at the ecosystem level - EVP
(Homolová et al.,2013), plant physiological conditions, and in some cases direct information on functional aspects of the ecosystem (Hilker et al., 2008), i.e., on EFPs. The possibilities offered by new remote sensing techniques allowed several authors to develop new concept of optically distinguishable PFTs ("optical type" according to Ustin and Gamon (2010)) and to directly estimate EVPs beyond the concept of PFTs. Moreover, remote sensing could be a way to address the scaling approach to derive EVPs or better integrate in situ plant traits measurements (Asner et al., 2015). This would allow a more direct link between EFPs and EVP derived from remote sensing information (e.g., Ustin and Gamon, 2010). This information can be obtained at different spatial and temporal scales by using satellite products, airborne platforms with hyperspectral sensors, or by measuring them in the proximity of the surface (usually referred to as near-surface RS or proximal sensing) (Ustin et al., 2004; Gamon et al., 2006; Balzarolo et al., 2011). To explore the possibility of linking traits scaled at the ecosystem level to eddy covariance flux data and eventually EFPs, near surface RS and airborne hyperspectral data are most suited. In the Table 2 we list some literature examples of how plant traits, vegetation structural properties, and EFPs relevant for the proposed framework have been successfully retrieved.

Retrieval of plant traits from RS is well reported in the literature (for a review see Homolová et al., 2013). Yet obtaining plant traits time series or maps usable to predict EFPs from RS data is not straightforward. Plant traits and canopy properties that can be derived from RS data are mainly those that describe a relationship and interaction between absorbed/reflected light and vegetation structure/function (Roelofsen et al., 2014), i.e., structural traits affecting light scattering (e.g., Ustin, 2013). For instance, variations in foliar photosynthetic pigments affect mainly the spectrum in the visible region (400-700 nm), variations in leaf structure affect the near infrared region $(700-1300 \mathrm{~nm})$, while variations in water content and protein content (as well as other nutrients such as $P$ ) affect the shortwave infrared region (1300-2500 nm) (e.g., Mutangao and Kumar, 2007; Ramoelo et al., 2013). Therefore, the typology of plant traits and EVPs that can be retrieved via RS depends primarily on the spectral characteristics and resolution of the sensors.

One of the main criticisms in the use of RS information for the proposed approach is that scaling RS information from leaf 
Table 2

List of plant traits, canopy structure, and EFPs that can be retrieved from RS at leaf and canopy ecosystem scale. Methods of estimation and associated references are also reported.

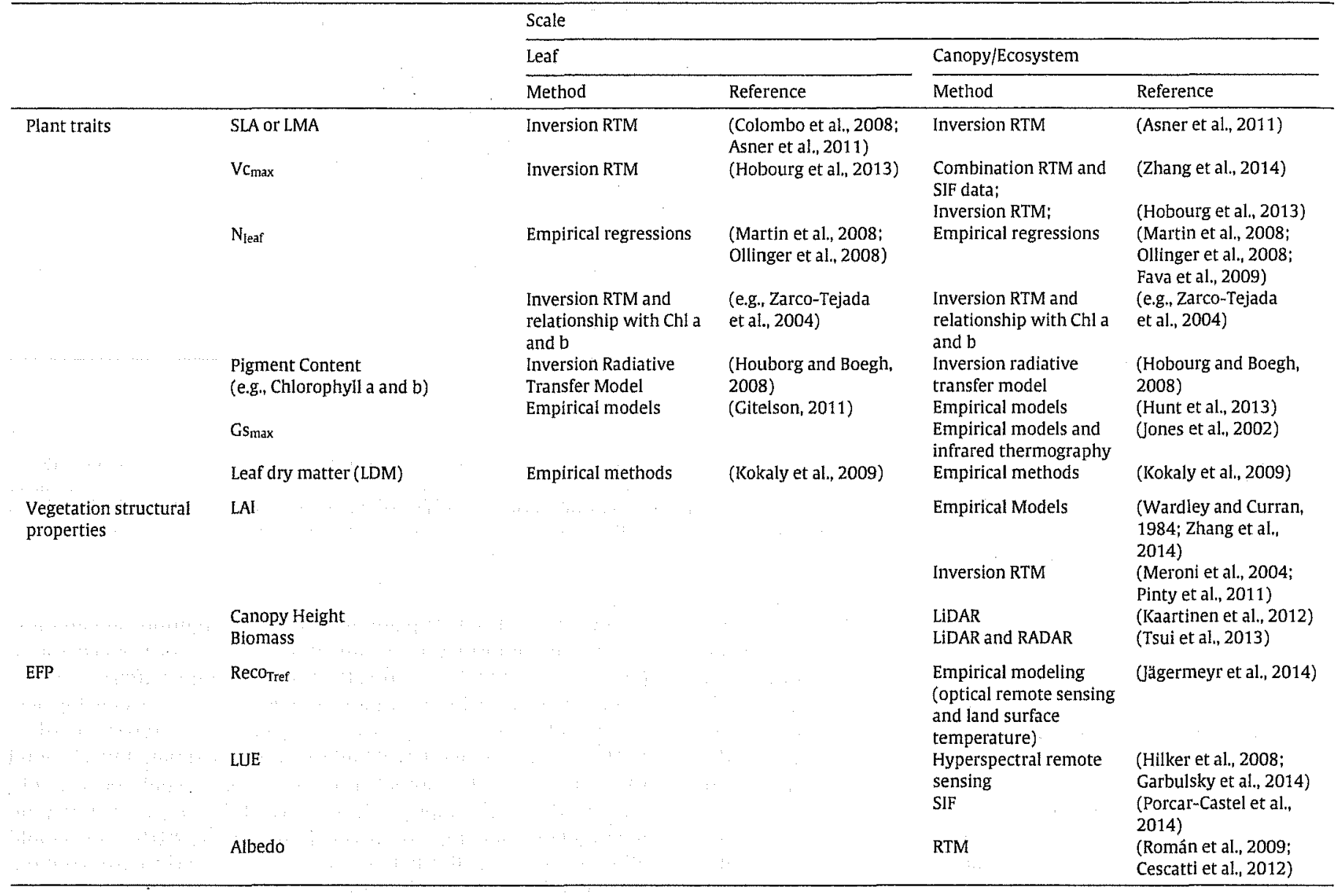

to ecosystem level and vice versa is still challenging (Malenovský et al., 2013). At the leaf level, a variety of RS techniques and sensors has been largely applied to monitor key plant traits such as leaf chlorophyll a and b content (Gitelson et al., 2005; Dash and Curran, 2007; Houborg and Boegh, 2008), relative extractable water content in leaves (Colombo et al., 2008) and nutrient concentrations, in particular foliar nitrogen content (e.g., Zarco-Tejada et al., 2004). But at the ecosystem level, there are several confounding factors in addition to uncertainties related to the sensors used (e.g., spectral resolution). Several confounding factors that influence the upscaled results of the leaf level reflectance include: contamination of the signal by aerosols and clouds (in particular for airborne and satellite data), and the canopy structure and soil which affects accuracy of the retrieval of traits (e.g., le Maire et al., 2008; Knyazikhin et al., 2012). Thus, a key challenge is the separation of the leaf contribution associated with changes in plant traits (or a correlated variable) from those by canopy structure (Houborg et al. 2013). The main techniques currently used to upscale and downscale RSinformation from the leaf to the ecosystem level are physically based radiative transfer models, spectral mixing and unmixing techniques, and data fusion (Malenovský et al., 2007).

Radiative transfer models based on coupled leaf optics and canopy reflectance models are often used in inverse mode to estimate plant traits and canopy biochemistry (e.g., pigments, foliar $\mathrm{N}$ content) at ecosystem level from the reflectance observed with spectrometers or airborne/satellite platforms (Baret and Buis, 2008; Jacquemoud et al., 2009; Knyazikhin et al., 2012; Ustin, 2013). One typical example is the estimation of chlorophyll $a$ and $b$, done by inverting leaf optical properties model (e,g., Jacquemoud and Baret, 1990) coupled with canopy directional reflectance models while accounting for canopy structure (e.g. the Scattering by Arbitrary Inclined Leaves model, SAILH). Despite their potential, the estimation of traits from radiative transfer models is not trivial, as it requires a heavy parameterization of the canopy structure characteristics. Moreover, the inverse problem is often ill-posed or prone to equifinality (e.g., Combal et al. 2003), hampering the correct estimation of the parameters (e.g., plant traits).

Empirical methods are also often used instead of radiative transfer models. These methods rely on the parameterization of a regression model between in situ plant traits observations and (1) reflectance in a portion of the electromagnetic spectrum sensitive to variations of the targeted trait, or (2) an arithmetic combination of different portions of the spectrum (i.e., vegetation indices) (e.g., Colombo et al., 2008; Chen et al., 2010). Empirical models can be built directly for canopy scale, or at the leaf level and upscaled to the canopy level. However, these methods are quite often site-specific and sampling condition dependent, sensor-specific (in particular dependent on the spectral resolution), might change in space and time, and the retrieval of leaf canopy traits is often hampered by the difficulty in decoupling the contributions of the targeted trait and LAI (e.g., Gobron et al. 1997; Colombo et al., 2008). Moreover, empirical methods have demonstrated to have less predictive power in many cases compared to radiative transfer and physically based models (Malenovský et al., 2013).

Many plant traits have been successfully estimated using RS data, such as canopy and leaf $\mathrm{N} \%$, and chlorophyll a and b content. 
Yet the estimation of some relevant key traits is still problematic. For instance, White et al. (2000) emphasize that leaf mass per leaf area (LMA, the inverse of SLA) is one of the key parameters to accurately simulate the temporal variability of GPP and NPP with terrestrial biosphere models. However, the estimation of LMA from RS is far from precise. Homolová et al. (2013) reviewed the literature and reported an average relative RMSE of $45.0 \%$ ( $1 \mathrm{sd} 30.0 \%$ ) for the LMA retrieval, regardless of the method used for the estimation. One of the main problems is that LMA estimations are sensitive to variations in the portion of the spectrum that is also affected by water absorption which can act as a confounding factor (e.g., Asner et al., 2011).

RS applications to estimate EFPs directly have not yet been fully explored. Albedo is one of the key EFPs (Table 1), and its variability in time and space can be globally retrieved through the use of near-surface and RS products. Nevertheless, current approaches for measuring in situ albedo are not adequate to describe mixed or highly heterogeneous landscapes such as mixed forests, open shrublands, savannas, and croplands (Cescatti et al., 2012). Also EFPs related to photosynthesis (e.g., LUE, Table 1) might be inferred by RS measurements such as sun-induced chlorophyll fluorescence (SIF, Porcar-Castell et al., 2014) and photochemical reflectance index (PRI) (Gamon et al., 1992), which have proven to be valuable methods for the direct assessment of plant photosynthesis, from the ecosystem scale (Meroni et al,, 2009; Damm et al., 2010) to regional and global scale (e.g., Guanter et al., 2014). These measurements can in principle be used to directly estimate ecosystem LUE (Garbulsky et al, 2014), ecosystem maximum carboxylation rate $\left(V_{\text {cmax }}\right)$ via empirical relationships (Houborg et al., 2013), or by inverting radiative transfer models simulating SIF, such as Soil Canopy Observation Photosynthesis Energy balance model - SCOPE (e.g., van der Tol et al. 2009; Zhang et al., 2014). Nevertheless, the estimation of these EFPs from time series of SIF or PRI is not a trivial task given the series of confounding factors that affect the signal at canopy and ecosystem scale, in particular the algorithm retrieval for SIF (e.g., Meroni et al., 2009), variation of LAI and directional effects (e.g., Garbulsky et al.,2014), and also the mechanistic understanding of the link between SIF and photosynthesis at the seasonal scale (Porcar-Castell et al., 2014). Still, it seems promising to infer direct information on parameters related to EFPs using RS.

\section{Conclusions}

We propose a pathway to empirically analyze the intrinsic biotic controls of terrestrial ecosystem functioning based on the conceptualization of ecosystem functional properties (EFPs) as indicators of ecosystem functional state. Since the variability of EFPs can only partly be explained by environmental drivers, we expect that biotic controls, represented by plant abundance and traits, measured in situ or via RS (ecosystem vegetation properties, EVPs) will explain an additional important component of the variation in ecosystem functioning. We provide examples how EFPs and biotic correspondents (here EVPs) can be derived from ecosystem fluxes, $\mathrm{RS}$, and plant traits considering information on canopy structure. However, further work is necessary to test how to best derive EFPs, link these to EVPs, and assess the uncertainties associated to the different methods. We anticipate our framework will encourage the combination of ecosystem flux studies with EFPs, RS, and in situ observed plant traits (as EVPs), with the final goal to increase our understanding of how environmental drivers shape ecosystems and vice versa. The outcome of such empirical studies will complement complex predictive terrestrial biosphere models and help to better predict long term trajectories of ecosystem functioning and ecosystem services under climate change.

\section{Acknowledgments}

T.M. acknowledges the International Max Planck Research School for global biogeochemical cycles. The study has been supported by the TRY initiative on plant traits (http://www. try-db.org), hosted at the Max Planck Institute for Biogeochemistry and currently supported by DIVERSITAS/Future Earth and the German Centre for Integrative Biodiversity Research (iDiv) Halle-Jena-Leipzig. We wish to thank all the people who made the data on N\% available in TRY (Cornelissen, 1996; Cornelissen et al., 1996; Bahn et al., 1999; Medlyn et al., 1999; Meziane and Shipley, 1999; Niinemets, 2001; Cornelissen et al., 2003b; Loveys et al., 2003; Quested et al., 2003; Ogaya and Penuelas, 2003; Cornelissen et al., 2004; Diaz et al., 2004; Wright et al., 2004; Bakker et al., 2005; Craine et al., 2005; Han et al., 2005; Louault et al., 2005; Bakker et al., 2006; Kazakou et al., 2006; Kerkhoff et al., 2006; Preston et al., 2006; Campbell et al., 2007; Garnier et al., 2007; Cornwell et al., 2008; Reich et al., 2008; Craine et al., 2009; Kattge et al., 2009; Reich et al., 2009; Freschet et al., 2010; Laughlin et al., 2010; Ordoñez et al., 2010; Willis et al., 2010). We thank Lee Miller for his kind language check.

\section{Appendix A. Supplementary data}

Supplementary data associated with this article can be found, in the online version, at http://dx.doi.org/10.1016/j.jag.2015.05.009

\section{References}

Albert, $\mathrm{C} . \mathrm{H}_{*}$ 2015. Intraspecific trait variability matters. J. Veg. Sci. 26 (1), 7-8. Asner, G.P., Martin, R.E., Anderson, C.B., Knapp, D.E., 2015. Quantifying forest canopy traits: imaging spectroscopy versus field survey. Remote Sens. Environ. $158,15-27$.

Asner, G.P., Martin, R.E., Tupayachi, R., Emerson, R., Martinez, P., Sinca, F., Powell, G.V.N., Wright, S.J., Lugo, A.E., 2011. Taxonomy and remote sensing of leaf mass per area (LMA) in humid tropical forests. Ecol. Appl. 21 (1), 85-98.

Aubinet, M., Grelle, A., Ibrom, A., Rannik, U., Moncrieff, J., Foken, T., Kowalski, A.S., Martin, P.H., Berbigier, P., Bernhofer, C., Clement, R., Elbers, J., Granier, A., Grunwald, T., Morgenstern, K., Pllegaard, K., Rebmann, C., Snijders, W., Valentini, R., Vesala, T., 2000. Estimates of the annual net carbon and water exchange of forests: the EUROFLUX methodology. Adv. Ecol. Res. 30 (30), $113-175$.

Bahn, M., Wohlfahrt, G., Haubner, E, Horak, I, Michaeler, W., Rottmar, K, Tappeiner, U., Cernusca, A. 1999. Leaf photosynthesis, nitrogen contents and specific leaf area of 30 grassland species in differently managed mountain ecosystems in the Eastern Alps. In: Cernusca, A., Tappeiner, U., Bayfield, N. (Eds.), Land-Use Changes in European Mountain Ecosystems. Ecomont Concept and Results. Blackwell Wissenschaft, Berlin, pp. 247-255.

Bakker, C., Rodenburg, J, van Bodegom, P.M., 2005. Effects of Ca-and Fe-rich seepage on $\mathrm{P}$ availability and plant performance in calcareous dune soils. Plant Soil $275(1-2), 111-122$.

Bakker, C., Van Bodegom, P.M., Nelissen, H.J.M., Ernst, W.H.O., Aerts, R, 2006. Plant responses to rising water tables and nutrient management in calcareous dune slacks. Plant Ecol. 185 (1), 19-28.

Baldocchi, D., 2008. Breathing of the terrestrial biosphere: lessons learned from a global network of carbon dioxide flux measurement systems. Aust. J. Bot. 56 (1), 1-26.

Baldocchi, D., Falge, E., Gu, L.H., Olson, R, Hollinger, D., Running, S., Anthoni, P., Bernhofer, C., Davis, K., Evans, R., Fuentes, J., Goldstein, A., Katul, G., Law, B., Lee, X.H., Malhi, Y., Meyers, T., Munger, W., Oechel, W., Pilegaard, K.T.P.U.K., Schmid, H.P., Valentini, R, Verma, S., Vesala, T., Wilson Wofsy, K,S., 2001. FLUXNET: a new tool to study the temporal and spatial variability of ecosystem-scale carbon dioxide, water vapor, and energy flux densities, Bull. Am. Meteorol. Soc. 82 (11), 2415-2434.

Baldocchi, D.D., Hicks, B.B., Meyers, T.P., 1988. measuring biosphere-atmosphere exchanges of biologically related gases with micrometeorological methods. Ecology $69(5), 1331-1340$.

Balzarolo, M., Anderson, K., Nichol, C., Rossini, M., Vescovo, L, Arriga, N., Wohlfahrt, G., Calvet, J.C., Carrara, A., Cerasoli, S., Cogliati, S., Daumard, F., Eklundh, L., Elbers, J.A., Evrendilek, F., Handcock, R.N., Kaduk, J., Klumpp, K., Longdoz, B., Matteicci, G., Meroni, M., Montagnani, L., Ourcival, J.M., Sanchez-Canete, E.P., pontailler, J.Y., Juszczak, R., Scholes, B., M, 2011. Ground-based optical measurements at european flux sites: a review of methods, instruments and current controversies. Sensors 11 (8), 7954-7981.

Baret, F., Buis, S., 2008. Estimating canopy characteristics from remote sensing observations: review of methods and associated problems. Adv. Land Remote Sens., 173-201, Chapter 7. 
Beer, C., Ciais, P., Reichstein, M., Baldocchi, D., Law, B.E., Papale, D., Soussana, J.F., Ammann, C., Buchmann, N., Frank, D., Gianelle, D. Janssens, L.A., Knohl, A., Kostner, B., Moors, E., Roupsard, O., Verbeeck, H., Vesala, T., Williams, C.A., Wohlfahrt, G., 2009. Temporal and among-site variability of inherent water use efficiency at the ecosystem level. Global Biogeochem. Cycles, 23.

Bonan, G.B., 2008. Forests and climate change: forcings, feedbacks, and the climate benefits of forests. Science 320 (5882), 1444-1449.

Box, E.0., 1996. Plant functional types and climate at the global scale. J. Veg. Sci. 7 (3), 309-320.

Brovkin, V., van Bodegom, P.M., Kleinen, T., Wirth, C., Cornwell, W.K., Cornelissen, J.H.C., Kattge, J., 2012. Plant-driven variation in decomposition rates improves projections of global litter stock distribution. Biogeosciences $9(1), 565-576$.

Buckley, T,N., 2005. The control of stomata by water balance. New Phytol. $168(2)$, 275-291.

Campbell, C., Atkinson, L., Zaragoza-Castells, J., Lundmark, M., Atkin, O., Hurry, V., 2007. Acclimation of photosynthesis and respiration is asynchronous in response to changes in temperature regardless of plant functional group. New Phytol. $176(2), 375-389$.

Cescatti, A., Marcolla, B., Vannan, S.K.S., Pan, J.Y., Roman, M.O., Yang, X.Y., Ciais, P., Cook, R.B., Law, B.E., Matteucci, G., Migliavacca, M., Moors, E., Richardson, A.D. Seufert, G., Schaaf, C.B., 2012. Intercomparison of MODIS albedo retrievals and in situ measurements across the global FLUXNET network. Remote Sens. Environ. 121, 323-334.

Chapin, F.S., Zavaleta, E.S., Eviner, V.T., Naylor, R.L., Vitousek, P.M., Reynolds, H.L., Hooper, D.U., Lavorel, S, Sala, O.E., Hobbie, S.E., Mack, M.C., Diaz, S., 2000. Consequences of changing biodiversity. Nature 405 (6783), 234-242.

Chapin, F.S., Sala, O.E., Burke, I.C., Grime, J.P., Hooper, D.U., Lauenroth, W.K., Lombard, A., Mooney, H.A., Mosier, A.R., Naeem, S., Pacala, S.W., Roy, J., Steffen, W.L., Tilman, D., 1998. Ecosystem consequences of changing biodiversity experimental evidence and a research agenda for the future. Bioscience 48 (1), $45-52$.

Chen, P.F., Haboudane, D., Tremblay, N., Wang, J,H., Vigneault, P., Li, B.G., 2010. New spectral indicator assessing the efficiency of crop nitrogen treatment in corn and wheat. Remote Sens. Environ. 114 (9), 1987-1997.

Cleveland, C.C., Townsend, A.R., Taylor, P., Alvarez-Clare, S., Bustamante, M.M.C., Chuyong, G., Dobrowski, S.Z., Grierson, P., Harms, K.E., Houlton, B.Z., Marklein A., Parton, W., Porder, S., Reed, S.C., Sierra, C.A., Silver, W.L., Tanner, E.V.J., Wieder, W.R., 2011. Relationships among net primary productivity, nutrients and climate in tropical rain forest: a pan-tropical analysis. Ecol. Lett. 14 (9), 939-947.

Colombo, R., Merom, M., Marchesi, A., Busetto, L., Rossini, M., Giardino, C., Panigada, $C_{,}, 2008$. Estimation of leaf and canopy water content in poplar plantations by means of hyperspectral indices and inverse modeling. Remote Sens. Environ. $112(4), 1820-1834$.

Combal, B., Baret, F., Weiss, M., Trubuil, A., Mace, D., Pragnere, A., Myneni, R., Knyazikhin, Y., Wang, L., 2003. Retrieval of canopy biophysical variables from bidirectional-reflectance - using prior information to solve the ill-posed inverse problem. Remote Sens. Environ, 84 (1), 1-15.

Cordlandwehr, V., Meredith, R.L., Ozinga, W.A., Bekker, R.M., van Groenendael, J.M., Bakker, J.P., 2013. Do plant traits retrieved from a database accurately predict on-site measurements? J. Ecol, 101 (3), 662-670.

Cornelissen, J.H.C., Quested, H.M., Gwynn-Jones, D., Van Logtestijn, R.S.P., De Beus M.A.H., Kondratchuk, A., Callaghan, T.V., Aerts, R., 2004. Leaf digestibility and litter decomposability are related in a wide range of subarctic plant species and types. Funct. Ecol, $18(6), 779-786$.

Cornelissen, J.H.C., Lavorel, S., Garnier, E., Diaz, S., Buchmann, N., Gurvich, D.E., Reich, P.B., ter Steege, H., Morgan, H.D., van der Heijden, M.G.A., Pausas, J.G., Poorter, H., 2003a. A handbook of protocols for standardised and easy measurement of plant functional traits worldwide. Aust. J. Bot. 51 (4), 335-380.

Cornelissen, J.H.C., Cerabolini, B., Castro-Diez, P., Villar-Salvador, P., Montserrat-Marti, G., Puyravaud, J.P., Maestro, M., Werger, M.J.A., Aerts, R., $2003 \mathrm{~b}$. Functional traits of woody plants: correspondence of species rankings between field adults and laboratory-grown seedlings? J. Veg. Sci. 14 (3), 311-322.

Cornelissen, J.H.C., 1996. An experimental comparison of leaf decomposition rates in a wide range of temperate plant species and types. J. Ecol. 84, 573-582.

Cornelissen, J.H.C., Diez, P.C., Hunt, R., 1996. Seedling growth, allocation and leaf attributes in a wide range of woody plant species and types. J. Ecol. 84 (5), 755-765.

Cornwell, W.K., Cornelissen, J.H.C., Amatangelo, K., Dorrepaal, E., Eviner, V.T., Godoy, O., Hobbie, S.E., Hoorens, B., Kurokawa, H., Perez-Harguindeguy, N., Quested, H.M., Santiago, L.S., Wardle, D.A., Wright, I,J., Aerts, R., Allison, S.D., van Bodegom, P., Brovkin, V., Chatain, A., Callaghan, T.V., Diaz, S., Garnier, E., Gurvich, D.E., Kazakou, E., Klein, J.A., Read, J., Reich, P.B., Soudzilovskaia, N.A., Vaieretti, M.V., Westoby, M., 2008. Plant species traits are the predominant control on litter decomposition rates within biomes worldwide. Ecol. Lett. 11 (10), 1065-1071.

Craine, J.M., Elmore, A.J., Aidar, M.P.M., Bustamante, M., Dawson, T.E., Hobbie, E.A., Kahmen, A., Mack, M.C., McLauchlan, K.K., Michelsen, A., Nardoto, G.B., Pardo, L.H., Penuelas, J., Reich, P.B., Schuur, E.A.G., Stock, W.D., Templer, P.H., Virginia, R.A., Welker, J.M., Wright, 1.j., 2009. Global patterns of foliar nitrogen isotopes and their relationships with climate, mycorrhizal fungi, foliar nutrient concentrations, and nitrogen availability. New Phytol. 183 (4), 980-992.

Craine, J.M., Lee, W.G., Bond, W.J., Williams, R.J., Johnson, L.C., 2005. Environmental constraints on a global relationship among leaf and root traits of grasses. Ecology 86 (1), 12-19.
Damm, A., Elbers, J., Erler, A., Gioli, B., Hamdi, K., Hutjes, R., Kosvancova, M., Meroni, M., Miglietta, F., Moersch, A., Moreno, J., Schickling, A., Sonnenschein, R., Udelhoven, T., van der Linden, S., Hostert, P., Rascher, U., 2010. Remote sensing of sun-induced fluorescence to improve modeling of diurnal courses of gross primary production (GPP). Global Change Biol. 16(1), 171-186.

Dash, J., Curran, P.J., 2007. Evaluation of the MERIS terrestrial chlorophyll index (MTCI). Adv, Space Res. 39 (1), 100-104.

de Bello, F., Lavorel, S., Diaz, S., Harrington, R. Cornelissen, J.H.C., Barogett, R.D. Berg, M.P., Cipriotti, P., Feld, C.K., Hering, D., da Silva, P.M., Potts, S.G., Sandin, L., Sousa, J.P., Storkey, J., Wardle, D.A., Harrison, P.A., 2010. Towards an assessment of multiple ecosystem processes and services via functional traits. Biodivers. Conserv. 19(10), 2873-2893.

DeLucia, E.H., Drake, J.E., Thomas, R.B., Gonzalez-Meler, M., 2007. Forest carbon use efficiency: is respiration a constant fraction of gross primary production? Global Change Biol. 13 (6), 1157-1167.

Díaz, S., Hodgson, J.G., Thompson, K., Cabido, M., Cornelissen, J.H.C., Jalili, A., Montserrat-Marti, G., Grime, J.P., Zarrinkamar, F., Asri, Y., Band, S.R., Basconcelo, S., Castro-Diez, P., Funes, G., Hamzehee, B., Khoshnevi, M., Perez-Harguindeguy, N., Perez-Rontome, M.C., Shirvany, F.A., Vendramini, F, Yazdani, S., Abbas-Azimi, R., Bogaard, A., Boustani, S., Charles, M., Dehghan, M., de Torres-Espuny, L., Falczuk, V., Guerrero-Campo, J., Hynd, A., Jones, G., Kowsary, E., Kazemi-Saeed, F., Maestro-Martinez, M., Romo-Diez, A., Shaw, S., Siavash, B., Villar-Salvador, P., Zak, M.R., 2004. The plant traits that drive ecosystems: evidence from three continents. J. Veg. Sci. 15 (3), 295-304.

Dunn, A.L., Barford, C.C., Wofsy, S.C., Goulden, M.L., Daube, B.C., 2007. A long-term record of carbon exchange in a boreal black spruce forest: means, responses to interannual variability, and decadal trends. Global Change Biol. 13 (3), $577-590$.

Falge, E., Baldocchi, D., Olson, R., Anthoni, P., Aubinet, M., Bernhofer, C., Burba, G. Ceulemans, R., Clement, R., Dolman, H., Granier, A., Gross, P., Grunwald, T., Hollinger, D., Jensen, N.O., Katul, G., Keronen, P., Kowalski, A., Lai, C.T., Law, B.E. Meyers, T., Moncrieff, H., Moors, E., Munger, J.W., Pilegaard, K., Rannik, U., Rebmann, C., Suyker, A., Tenhunen, J., Tu, K., Verma, S., Vesala, T., Wilson, K., Wofsy, S., 2001. Gap filling strategies for defensible annual sums of net ecosystem exchange. Agric. For. Meteorol. 107 (1), 43-69.

Fava, F., Colombo, R., Bocchi, S., Meroni, M., Sitzia, M., Fois, N., Zucca, C., 2009. Identification of hyperspectral vegetation indices for Mediterranean pasture characterization. Int. J. Appl. Earth Observ. Geoinf. 11 (4), 233-243.

Field, C.B., Chapin, F.S., Matson, P.A., Mooney, H.A., 1992. Responses of terrestrial ecosystems to the changing atmosphere - a resource-based approach. Ann. Rev. Ecol. Syst. 23, 201-235.

Field, C., Mooney, H.A., 1986. The photosynthesis - nitrogen relationship in wild plants. In: Givnish, T.J. (Ed.), On the Economy of Plant Form and Function. Cambridge University Press, Cambridge, pp. 22-55.

Fisher, J.B., S. Sweeney, E.R. Brzostek, T.P. Evans, N.A. Bourg, R.P. Phillips (in review). Remote sensing of mycorrhizal associations from canopy spectral properties. Submitted to: Nature Plants.

Foken, T., Wichura, B., 1996. Tools for quality assessment of surface-based flux measurements. Agric. For. Meteorol, 78 (1-2), 83-105.

Freschet, G.T., Cornelissen, J.H.C., van Logtestijn, R.S.P., Aerts, R., 2010. Evidence of the 'plant economics spectrum' in a subarctic flora. J. Ecol. 98 (2), 362-373.

Friend, A.D., Cox, P.M., 1995. Modeling the effects of atmospheric $\mathrm{CO}_{2}$ on vegetation atmosphere interactions. Agric. For. Meteorol. 73 (3-4), 285-295.

Gamon, J.A., Rahman, A.F., Dungan, J.L., Schildhauer, M., Huemmrich, K.F., 2006. Spectral network (SpecNet) - what is it and why do we need it? Remote Sens. Environ. 103 (3), 227-235.

Gamon, J.A., Penuelas, J., Field, C.B., 1992. A narrow-waveband spectral index that tracks diurnal changes in photosynthetic efficiency. Remote Sens. Environ. 41 (1), 35-44.

Garbulsky, M.F., Filella, I., Verger, A., Penuelas, ]., 2014. Photosynthetic light use efficiency from satellite sensors: from global to Mediterranean vegetation. Environ. Exp. Bot. 103, 3-11

Garnier, E., Lavorel, S., Ansquer, P., Castro, H., Cruz, P., Dolezal, J., Eriksson, O., Fortunel, C., Freitas, H., Golodets, C., Grigulis, K., Jouany, C., Kazakou, E., Kigel, J., Kleyer, M., Lehsten, V., Leps, J., Meier, T., Pakeman, R., Papadimitriou, M., Papanastasis, V.P., Quested, H., Quetier, F., Robson, M., Roumet, C., Rusch, G., Skarpe, C., Sternberg, M., Theau, J.F., Thebault, A., Vile, D., Zarovali, M.P., 2007. Assessing the effects of land-use change on plant traits, communities and ecosystem functioning in grasslands: a standardized methodology and lessons from an application to 11 European sites. Ann. Bot. 99 (5), 967-985.

Garnier, E., Cortez, J., Billes, G., Navas, M.L., Roumet, C., Debussche, M., Laurent, G., Blanchard, A., Aubry, D., Bellmann, A., Neill, C., Tossaint, J.P., 2004. Plant functional markers capture ecosystem properties during secondary succession. Ecology 85 (9), 2630-2637.

Gilmanov, T.G., Verma, S.B., Sims, P.L., Meyers, T.P., Bradford, J.A., Burba, G.G., Suyker, A.E., 2003. Gross primary production and light response parameters of four Southern Plains ecosystems estimated using long-term $\mathrm{CO}_{2}$-flux tower measurements. Global Biogeochem. Cycles 17 (2).

Gitelson, A.A., Vina, A., Ciganda, V., Rundquist, D.C., Arkebauer, T.J., 2005. Remote estimation of canopy chlorophyll content in crops. Geophys. Res. Lett. 32 (8).

Givnish, T.J., 1986. On the Economy of Plant Form and Function. University of Cambridge.

Gobron, N., Pinty, B., Verstraete, M.M., 1997. Theoretical limits to the estimation of the leaf area index on the basis of visible and near-infrared remote sensing data. leee Trans. Geosci. Remote Sens. 35 (6), 1438-1445. 
Goll, D.S., Brovkin, V., Parida, B.R., Reick, C.H., Kattge, J., Reich, P.B., van Bodegom, P.M., Niinemets, $U ., 2012$. Nutrient limitation reduces land carbon uptake in simulations with a model of combined carbon, nitrogen and phosphorus cycling. Biogeosciences $9(9), 3547-3569$.

Green, D.S., Erickson, J.E., Kruger, E.L., 2003. Foliar morphology and canopy nitrogen as predictors of light-use efficiency in terrestrial vegetation. Agric. For, Meteorol, $115(3-4), 163-171$.

Grime, J.P., 1988. Comparative Plant Ecology: A Functional Approach to Common British Species. Unwin Hyman, London.

Grime, J.P., 1979. Plant Strategies, Vegetation Processes, and Ecosystem Properties. Wiley.

Guanter, L., Zhang, Y.G., Jung, M., Joiner, J., Voigt, M., Berry, J.A., Frankenberg, C., Huete, A.R., Zarco-Tejada, P., Lee, J.E., Moran, M.S., Ponce-Campos, G., Beer, C., Camps-Valls, G., Buchmann, N., Gianelle, D., Klumpp, K., Cescatti, A., Baker, J.M. Griffis, T.J., 2014. Global and time-resolved monitoring of crop photosynthesis with chlorophyll fluorescence. Proc. Nat. Acad. Sci. U. S. A. 111 (14), E1327-E1333.

Han, W.X., Fang, J.Y., Guo, D.L., Zhang, Y., 2005. Leaf nitrogen and phosphorus stoichiometry across 753 terrestrial plant species in China. New Phytol. 168 (2), 377-385

Henderson, E.B., Ohmann, J.L., Gregory, M.J., Roberts, H.M., Zald, H., 2014. Species distribution modelling for plant communities: stacked single species or multivariate modelling approaches? Appl. Veg. Sci. 17 (3), 516-527.

Hernandez-Stefanoni, J.L., Ponce-Hernandez, R., 2006. Mapping the spatial variability of plant diversity in a tropical forest: comparison of spatial interpolation methods. Environ. Monit. Assess. 117 (1-3), 307-334.

Hilker, T', Coops, N.C., Wulder, M.A., Black, T.A., Guy, R.D., 2008. The use of remote sensing in light use efficiency based models of gross primary production: a review of current status and future requirements. Sci. Total Environ. 404 (2-3), 411-423.

Homolovâ, L., Maenovsky, Z., Clevers, J.G.P.W., Garcia-Santos, G., Schaeprnan, M.E., 2013. Review of optical-based remote sensing for plant trait mapping. Ecol. Complexity 15, 1-16.

Hooper, D.U., Chapin, F.S., Ewel, J.J., Hector, A., Inchausti, P., Lavorel, S., Lawton, J.H., Lodge, D.M., Loreau, M., Naeem, S., Schmid, B., Setala, H., Symstad, A.J. Vandermeer, J., Wardle, D.A., 2005. Effects of biodiversity on ecosystem functioning: a consensus of current knowledge. Ecol. Monogr. 75 (1) 3-35.

Houborg, R., Boegh, E., 2008. Mapping leaf chlorophyll and leaf area index using inverse and forward canopy reflectance modeling and SPOT reflectance data. Remote Sens. Environ. 112 (1), 186-202.

Houborg, R., Cescatti, A., Migliavacca, M., Kustas, W.P., 2013. Satellite retrievals of leaf chlorophyll and photosynthetic capacity for improved modeling of GPP. Agric. For. Meteorol. 177, 10-23.

Hunt, E.R., Doraiswamy, P.C., McMurtrey, J.E., Daughtry, C.S.T., Perry, E.M., Akhmedov, B., 2013. A visible band index for remote sensing leaf chlorophyll content at the canopy scale. Int. J. Appi. Earth Obs. Geoinf. 21, 103-112.

Jacquemoud, S., Baret, F., 1990. Prospect - a model of leaf optical-properties spectra. Remote Sens. Environ. 34 (2), 75-91.

Jacquemoud, S., Verhoef, W., Baret, F., Bacour, C., Zarco-Tejada, P.J., Asner, G.P., Francois, C., Ustin, S.L., 2009. PROSPECT plus SAIL models: a review of use for vegetation characterization. Remote Sens. Environ. 11 (3), S56-S66.

Jägermeyr, J., Gerten, D., Lucht, W., Hostert, P., Migliavacca, M., Nemani, R, 2014. A high-resolution approach to estimating ecosystem respiration at continental scales using operational satellite data. Global Change Biol. $20(4), 1191-1210$.

Jones, H. G., (2014). Plants and Microclimate A Quantitative Approach to Environmental Plant Physiology Third Edition PREFACE. Plants and Microclimate: A Quantitative Approach to Environmental Plant Physiology, 3rd Edition.

Jones, H.G., Stoll, M., Santos, T., de Sousa, C., Chaves, M.M., Grant, O.M., 2002. Use of infrared thermography for monitoring stomatal closure in the field: application to grapevine. J. Exp. Bot. 53 (378), 2249-2260.

Jung, M., Reichstein, M. Margolis, H.A., Cescatti, A., Richardson, A.D., Arain, M.A Arneth, A., Bernhofer, C., Bonal, D., Chen, J.Q., Gianelle, D., Gobron, N., Kiely, G. Kutsch, W., Lasslop, G., Law, B.E., Lindroth, A., Merbold, L., Montagnani, L, Moors, E.J, Papale, D., Sottocornola, M., Vaccari, F., Williams, C., 2011, Global patterns of land-atmosphere fluxes of carbon dioxide, latent heat, and sensible heat derived from eddy covariance, satellite, and meteorological observations. J. Geophys. Res. Biogeosci. 116.

Kaartinen, H., Hyyppa, J., Yu, X.W., Vastaranta, M., Hyyppa, H., Kukko, A., Holopainen, M., Heipke, C., Hirschmugl, M., Morsdorf, F., Naesset, E., Pitkanen, J., Popescu, S., Solberg, S., Wolf, B.M., Wu, J.C., 2012. An international comparison of individual tree detection and extraction using airborne laser scanning. Remote Sens. 4 (4), 950-974.

Kattge, J.S., Diaz, S., Lavorel, C., Prentice, P., Leadley, G., Bonisch, E., Garnier, M., Westoby, P.B., Reich, I.J., Wright, J.H.C., Cornelissen, C., Violle, S.P., Harrison, P.M., van Bodegom, M., Reichstein, B.J., Enquist, N.A., Soudzilovskaia, D.D., Ackerly, M., Anand, O., Atkin, M., Bahn, T.R., Baker, D., Baldocchi, R., Bekker, C.C., Blanco, B., Blonder, W.J., Bond, R., Bradstock, D.E., Bunker, F., Casanoves, J., Cavender-Bares, J.Q., Chambers, F.S., Chapin, J., Chave, D., Coomes, W.K., Cornwell, J.M., Craine, B.H., Dobrin, L., Duarte, W., Durka, J., Elser, G., Esser, M., Estiarte, W.F., Fagan, J., Fang, F., Fernandez-Mendez, A., Fidelis, B., Finegan, O., Flores, H., Ford, D., Frank, G.T., Freschet, N.M., Fyllas, R.V., Gallagher, W.A., Green, A.G., Gutierrez, T., Hickler, S.I, Higgins, J.G., Hodgson, A., Jalili, S., Jansen, C.A., Joly, A.J., Kerkhoff, D., Kirkup, K., Kitajima, M., Kleyer, S., Klotz, J.M.H., Knops, K., Kramer, I., Kuhn, H., Kurokawa, D., Laughlin, T.D., Lee, M., Leishman, F., Lens, T., Lenz, S.L., Lewis, J., Lloyd, J., Llusia, F., Louault, S., Ma, M.D., Mahecha,
P., Manning, T., Massad, B.E., Medlyn, J., Messier, A.T., Moles, S.C., Muller, K., Nadrowski, S., Naeem, U., Niinemets, S., Nollert, A., Nuske, R., Ogaya, J., Oleksyn, V.G., Onipchenko, Y., Onoda, J., Ordonez, G., Overbeck, W.A., Ozinga, S., et al., 2011. TRY - a global database of plant traits. Global Change Biol, 17 (9), 2905-2935.

Kattge, J., Knorr, W., Raddatz, T., Wirth, C., 2009. Quantifying photosynthetic capacity and its relationship to leaf nitrogen content for global-scale terrestrial biosphere models. Global Change Biol. 15 (4), 976-991.

Kazakou, E., Vile, D., Shipley, B., Gallet, C., Garnier, E., 2006. Co-variations in litter decomposition, leaf traits and plant growth in species from a Mediterranean old-field succession. Funct. Ecol. $20(1), 21-30$.

Kazakou, E., Violle, C., Roumet, C., Navas, M.-L., Vile, D., Kattge, J., Garnier, E., 2014. Are trait-based species rankings consistent across data sets and spatial scales? J. Veg. Sci. 25 (1), 235-247.

Kergoat, L., Lafont, S., Arneth, A., Le Dantec, V., Saugier, B., 2008. Nitrogen controls plant canopy light-use efficiency in temperate and boreal ecosystems. J. Geophys. Res. Biogeosci. 113 (G4).

Kerkhoff, A.J., Enquist, B.J., 2006. Ecosystem allometry: the scaling of nutrient stocks and primary productivity across plant communities. Ecol. Lett. 9 (4), 419-427.

Kerkhoff, A.J., Fagan, W.F., Elser, J.J., Enquist, B.J., 2006. Phylogenetic and growth form variation in the scaling of nitrogen and phosphorus in the seed plants. Am. Nat. 168 (4), E103-E122.

Knyazikhin, Y., Schull, M.A., Stenberg, P., Mottus, M., Rautiainen, M., Yang, Y., Marshak, A., Carmona, P.L., Kaufmann, R.K., Lewis, P., Disney, M.I., Vanderbilt V., Davis, A.B., Baret, F., Jacquemoud, S., Lyapustin, A., Myneni, R.B., 2012. Hyperspectral remote sensing of foliar nitrogen content. Proc. Nat. Acad. Sci. U. S. A. 110 (3), E185-E192.

Kokaly, R.F., Asner, G.P., Ollinger, S.V., Martin, M.E., Wessman, C.A., 2009. Characterizing canopy biochemistry from imaging spectroscopy and its application to ecosystem studies. Remote Sens, Environ. 113, S78-S91.

Laughlin, D.C., Leppert, J.J., Moore, M., Sieg, C.H., 2010. A multi-trait test of the leaf-height-seed plant strategy scheme with 133 species from a pine forest flora. Funct. Ecol. 24 (3), 493-501.

Lavorel, S., Garnier, E., 2002. Predicting changes in community composition and ecosystem functioning from plant traits: revisiting the Holy Grail. Funct. Ecol $16(5), 545-556$

le Maire, G., Francois, C., Soudani, K., Berveiller, D., Pontailler, J.Y., Breda, N., Genet, H., Davi, H., Dufrene, E, 2008. Calibration and validation of hyperspectral indices for the estimation of broadleaved forest leaf chlorophyll content, leaf mass per area, leaf area index and leaf canopy biomass. Remote Sens. Environ. $112(10), 3846-3864$

Lloyd, J., Taylor, J.A., 1994. On the temperature-dependence of soil respiration. Funct. Ecol. 8 (3), 315-323.

Louault, F., Pillar, V.D., Aufrere, J., Garnier, E., Soussana, J.F., 2005. Plant traits and functional types in response to reduced disturbance in a semi-natural grassland. J. Veg. Sci. 16 (2), 151-160.

Loveys, B.R., Atkinson, L.J., Sherlock, D.J., Roberts, R.L., Fitter, A.H., Atkin, O.K., 2003. Thermal acclimation of leaf and root respiration: an investigation comparing inherently fast- and slow-growing plant species. Global Change Biol. $9(6)$, 895-910.

Luo, Y.W., Doney, S.C., Anderson, L.A., Benavides, M., Berman-Frank, I., Bode, A. Bonnet, S., Boström, K.H., Böttjer, D., Capone, D.G., Carpenter, E.J., Chen, Y.L. Church, M.J, Dore, J.E., Falcón, L.I., Fernández, A., Foster, R.A., Furuya, K., Gómez, F., Gundersen, K., Hynes, A.M., Karl, D.M., Kitajima, S., Langlois, R.J., LaRoche, J., Letelier, R.M., Marañón, E., McGillicuddy Jr, D.J., Moisander, P.H., Moore, C.M., Mouriño-Carballido, B., Mulholland, M.R., Needoba, J.A., Orcutt, K.M., Poulton, A.J., Rahav, E., Raimbault, P., Rees, A.P., Riemann, L., Shiozaki, T., Subramaniam, A., Tyrrell, T., Turk-Kubo, K.A., Varela, M., Villareal, T.A., Webb, E.A., White, A.E. Wu, J., Zehr, J.P., 2012. Database of diazotrophs in global ocean: abundance, biomass and nitrogen fixation rates. Earth Syst. Sci. Data 4(1), 47-73.

Luyssaert, S., Reichstein, M, Schulze, E.D., Janssens, l.A., Law, B.E., Papale, D. Dragoni, D., Goulden, M.L., Granier, A., Kutsch, W.L., Linder, S., Matteucci, G. Moors, E., Munger, J.W., Pilegaard, K., Saunders, M., Falge, E.M., 2009. Toward a consistency cross-check of eddy covariance flux-based and biometric estimates of ecosystem carbon balance. Global Biogeochem. Cycles, 23.

Ma, S.Y., Baldocchi, D.D. Mambelli, S., Dawson, T.E., 2010. Are temporal variations of leaf traits responsible for seasonal and inter-annual variability in ecosystem $\mathrm{CO}_{2}$ exchange? Funct. Ecol. 25 (1), 258-270

Mahecha, M.D., Reichstein, M., Carvalhais, N., Lasslop, G., Lange, H., Seneviratne, S.I. Vargas, R., Ammann, C., Arain, M.A., Cescatti, A., Janssens, I.A., Migliavacca, M., Montagnani, L., Richardson, A.D., 2010. Global convergence in the temperature sensitivity of respiration at ecosystem level. Science 329 (5993), 838-840.

Mahecha, M.D., Reichstein, M., Lange, H., Carvalhais, N., Bernhofer, C., Grunwald, T. Papale, D., Seufert, G., 2007. Characterizing ecosystem-atmosphere interactions from short to interannual time scales. Biogeosciences 4(5), 743-758.

Malenovský, Z., Homolova, L., Zurita-Milla, R., Lukes, P., Kaplan, V., Hanus, I. Gastellu-Etchegorry, J.P., Schaepman, M.E., 2013. Retrieval of spruce leaf chlorophyll content from airborne image data using continuum removal and radiative transfer. Remote Sens. Environ. 131, 85-102.

Malenovský, Z., Bartholomeus, H.M., Acerbi-Junior, F.W., Schopfer, J.T., Painter, T.H., Epema, G.F., Bregt, A.K., 2007. Scaling dimensions in spectroscopy of soil and vegetation. Int. J. Appl. Earth Obs. Geoinf. 9 (2), 137-164

Martin, M.E., Plourde, L.C., Ollinger, S.V., Smith, M.L., McNeil, B.E., 2008. A generalizable method for remote sensing of canopy nitrogen across a wide range of forest ecosystems. Remote Sens. Environ. 112 (9), 3511-3519. 
Medlyn, B.E., Badeck, F.W., De Pury, D.G.G., Barton, C.V.M., Broadmeadow, M. Ceulemans, R., De Angelis, P., Forstreuter, M., Jach, M.E., Kellomaki, S., Laitat, E., Marek, M., Philippot, S., Rey, A., Strassemeyer, J., Laitinen, K., Liozon, R., Portier, B., Roberntz, P., Wang, K., Jarvis, P.G., 1999. Effects of elevated $\left[\mathrm{CO}_{2}\right]$ on photosynthesis in European forest species: a meta-analysis of model parameters. Plant Cell Environ. 22 (12), 1475-1495.

Meroni, M., Colombo, R., Panigada, C, 2004. Inversion of a radiative transfer model with hyperspectral observations for LAI mapping in poplar plantations. Remote Sens. Environ. 92 (2), 195-206.

Meroni, M., Rossini, M., Guanter, L., Alonso, L., Rascher, U., Colombo, R., Moreno, J., 2009. Remote sensing of solar-induced chlorophyll fluorescence: review of methods and applications. Remote Sens. Environ. 113 (10), 2037-2051.

Meziane, D., Shipley, B., 1999. Interacting determinants of specific leaf area in 22 herbaceous species: effects of irradiance and nutrient availability. Plant Cell Environ. 22 (5), 447-459.

Monteith. J.L., 1972. Solar-radiation and productivity in tropical ecosystems. J. Appl. Ecol. 9 (3), 747-766,

Mott, K.A., Parkhurst, D.E., 1991. Stomatal responses to humidity in air and helox. Plant Cell Environ. $14(5), 509-515$.

Mutangao, O., Kumar, L., 2007. Estimating and mapping grass phosphorus concentration in an African savanna using hyperspectral image data. Int. J. Remote Sens. $28(21), 4897-4911$.

Neher, D.A., 1999. Soil community composition and ecosystem processes comparing agricultural ecosystems with natural ecosystems. Agrofor. Syst. 45 (1-3), 159-185.

Niinemets, U., 2001. Global-scale climatic controls of leaf dry mass per area, density, and thickness in trees and shrubs. Ecology $82(2), 453-469$.

Niinemets, U., Keenan, T.F., Hallik, L., 2015. A worldwide analysis of within-canopy variations in leaf structural, chemical and physiological traits across plant functional types. New Phytol, 205 (3), 973-993.

Ogaya, R., Penuelas, J., 2003. Comparative field study of Quercus ilex and Phillyrea latifolia: photosynthetic response to experimental drought conditions. Environ. Exp. Bot. 50 (2), 137-148.

Ogle, K., Barber, J.J., Barron-Gafford, G.A., Bentley, L.P., Young, J.M., Huxman, T.E., Loik, M.E., Tissue, D.T., 2015. Quantifying ecological memory in plant and ecosystem processes. Ecol. Lett. 18 (3), 221-235.

Ollinger, S.V., Richardson, A.D., Martin, M.E., Hollinger, D.Y., Frolking; S.E, Reich, P.B., Plourde, L.C., Katul, G.G., Munger, J.W., Oren, R., Smithb, M.L., Bolstad, K.T.P.U.P.V., Cook, B.D., Day Martin, M.C.T.A., Monson, R.K., Schmid, H.P., 2008 Canopy nitrogen, carbon assimilation, and albedo in temperate and boreal forests: functional relations and potential climate feedbacks. Proc. Nat, Acad. Sci. U. S. A. 105 (49), $19336-19341$.

Ordoñez, J.C, van Bodegom, P.M., Witte, J.P.M., Bartholomeus, R.P., van Hal, J.R., Aerts, R., 2010. Plant strategies in relation to resource supply in mesic to wet environments: does theory mirror nature? Am. Natur, 175, 225-239.

Ordoñez, J.C., van Bodegom, P.M., Witte, J.P.M., Wright, I.J., Reich, P.B., Aerts, R, 2009. A global study of relationships between leaf traits, climate and soil measures of nutrient fertility. Glob. Ecol. Biogeogr, $18(2), 137-149$.

Pavlick, R., Drewry, D.T., Bohn, K., Reu, B., Kleidon, A., 2013. The jena diversity-dynamic global vegetation model (JeDi-DGVM): a diverse approach to representing terrestrial biogeography and biogeochemistry based on plant functional trade-offs. Biogeosciences 10(6), 4137-4177.

Perez-Harguindeguy, N., Diaz, S., Garnier, E., Lavorel, S., Poorter, H., Jaureguiberry, P., Bret-Harte, M.S., Cornwell, W.K., Craine, J.M., Gurvich, D.E., Urcelay, C., Veneklaas, E.J., Reich, P.B., Poorter, L., Wright, I.J., Ray. Enrico, P.L., Pausas, J.G., de Vos, A.C., Buchmann, N., Funes, G., Quetier, F., Hodgson, J.G., Thompson, K., Morgan, H.D., ter Steege, H., van der Heijden, M.G.A., Sack, L, Blonder, B., Poschlod, P., Vaieretti, M.V., Conti, G., Staver, A.C., Aquino, S., Cornelissen, J.H.C., 2013. New handbook for standardised measurement of plant functional traits worldwide, Aust. J. Bot. 61 (3), 167-234.

Pierce, L.L., Running, S.W., Walker, J., 1994. Regional-scale relationships of leaf-area index to specific leaf-area and leaf nitrogen-content. Ecol. Appl. $4(2)$, 313-321.

Pinty, B., Andredakis, I., Clerici, M., Kaminski, T., Taberner, M., Verstraete, M.M., Gobron, N., Plummer, S, Widlowski, J.L., 2011. Exploiting the MODIS albedos with the Two-stream Inversion Package (IRC-TIP): 1. Effective leaf area index, vegetation, and soil properties. J. Geophys. Res. Atmos., 116.

Porcar-Castell, A., Tyystjarvi, E., Atherton, J., van der Tol, C., Flexas, J., Pfundel, E.E., Moreno, J., Frankenberg, C., Berry, J.A., 2014, Linking chlorophyll a fluorescence to photosynthesis for remote sensing applications: mechanisms and challenges. J. Exp. Bot. 65 (15), 4065-4095.

Preston, K.A., Cornwell, W.K., DeNoyer, J.L., 2006. Wood density and vessel traits as distinct correlates of ecological strategy in 51 California coast range angiosperms. New Phytol. 170 (4), 807-818.

Quested, H.M., Cornelissen, J.H.C., Press, M.C., Callaghan, T.V., Aerts, R., Trosien, F., Riemann, P., Gwynn-Jones, D., Kondratchuk, A., Jonasson, S.E., 2003. Decomposition of sub-arctic plants with differing nitrogen economies: a functional role for hemiparasites. Ecology 84 (12), 3209-3221.

Ramoelo, A., Skidmore, A.K., Cho, M.A., Mathieu, R., Heitkonig, I.M.A. Dudeni-Tlhone, N., Schlerf, M., Prins, H.H.T, 2013. Non-linear partial least square regression increases the estimation accuracy of grass nitrogen and phosphorus using in situ hyperspectral and environmental data. Isprs J. Photogram. Remote Sens. 82, 27-40.

Reich, P.B., Rich, R.L., Lu, X.J., Wang, Y.P., Oleksyn, J., 2014, Biogeographic variation in evergreen conifer needle longevity and impacts on boreal forest carbon cycle projections. Proc. Nat. Acad. Sci, U. S. A. 111 (38), 13703-13708.
Reich, P.B., 2012. Key canopy traits drive forest productivity. Proc. Royal Soc. B-Biol. Sci. 279 (1736), 2128-2134.

Reich, P.B., 2010. The Carbon Dioxide Exchange. Science 329 (5993), 774-775.

Reich, P.B., Oleksyn, J., Wright, I.J., 2009, Leaf phosphorus influences the photosynthesis-nitrogen relation: a cross-biome analysis of 314 species. Oecologia $160(2), 207-212$.

Reich, P.B., Tjoelker, M.G., Pregitzer, K.S., Wright, I.J., Oleksyn, J., Machado, J.L., 2008. Scaling of respiration to nitrogen in leaves, stems and roots of higher land plants. Ecol. Lett. $11(8), 793-801$.

Reichstein, M., Bahn, M., Mahecha, M.D., Kattge, J., Baldocchi, D.D., 2014. Linking plant and ecosystem functional biogeography. Proc. Nat. Acad. Sci. U. S. A. 111 (38), 13697-13702.

Reichstein, M., Beer, C., 2008. Soil respiration across scales: the importance of a model-data integration framework for data interpretation. J, Plant Nutr. Soil Sci. $171(3), 344-354$.

Reichstein, M., Rey, A., Freibauer, A., Tenhunen, J, Valentini, R., Banza, J., Casals, P., Cheng, Y.F., Grunzweig, J.M., Irvine, J., Joffre, R., Law, B.E., Loustau, D., Miglietta F., Oechel, W., Ourcival, J.M., Pereira, J.S., Peressotti, A., Ponti, F., Qi, Y., Rambal, S., Rayment, M., Romanya, J., Rossi, F., Tedeschi, V., Tirone, G., Xu, M., Yakir, D., 2003. Modeling temporal and large-scale spatial variability of soil respiration from soil water availability, temperature and vegetation productivity indices. Global Biogeochem. Cycles $17(4)$.

Reshef, D.N., Reshef, Y.A., Finucane, H.K., Grossman, S.R., McVean, G., Turnbaugh, P.J., Lander, E.S., Mitzenmacher, M., Sabeti, P.C., 2011. Detecting novel associations in large data sets. Science 334 (6062), 1518-1524

Reu, B., Zaehle, S., Proulx, R., Bohn, K., Kleidon, A., Pavlick, R., Schmidtlein, S., 2011. The role of plant functional trade-offs for biodiversity changes and biome shifts under scenarios of global climatic change. Biogeosciences 8 (5). $1255-1266$.

Richardson, A.D., Hollinger, D.Y., Aber, J.D., Ollinger, S.V., Braswell, B.H., 2007. Environmental variation is directly responsible for short- but not long-term variation in forest-atmosphere carbon exchange. Global Change Biol 13 (4), 788-803.

Roelofsen, H.D., van Bodegom, P.M., Kooistra, L., Witte, J.P.M., 2014. Predicting leaf traits of herbaceous species from their spectral characteristics. Ecol. Evol, $4(6)$, 706-719.

Román, M.O., Schaaf, C.B., Woodcock, C.E., Strahler, A.H., Yang, X.Y., Braswell, R.H., Curtis, P.S., Davis, K.J., Dragoni, D., Goulden, M.L., Gu, L.H., Hollinger, D.Y., Kolb, T.E., Meyers, T.P., Munger, J.W., Privette, J.L., Richardson, A.D., Wilson, T.B., Wofsy, S.C., 2009. The MODIS (Collection V005) BRDF/albedo product: assessment of spatial representativeness over forested landscapes. Remote Sens. Environ. $113(11), 2476-2498$.

Ruimy, A., Jarvis, P.G., Baldocchi, D.D., Saugier, B., 1995. $\mathrm{CO}_{2}$ fluxes over plant canopy and solar radiation: a review. Adv. Ecol. Res. 26.

Scheiter, S., Langan, L., Higgings, S.I,, 2013. Next-generation dynamic global vegetation models: learning from community ecology. New Phytol, 198 (3), 957-969.

Schlesinger, W.H,, 1997. Biogeochemistry. Geotimes 42 (2), 44.

Shirke, P.A., Pathre, U.V., 2004. Influence of leaf-to-air vapour pressure deficit (VPD) on the biochemistry and physiology of photosynthesis in Prosopis juliflora. J. Exp. Bot. 55 (405), 2111-2120.

Shope, J.C., Peak, D., Mott, K.A., 2008. Stomatal responses to humidity in isolated epidermes. Plant Cell Environ. 31 (9), 1290-1298.

Southwood, T.R.E., 1988. Tactics, strategies and templets. Oikos 52 (1), 3-18.

Stoy, P.C., Richardson, A.D. Baldocchi, D.D., Katul, G.G., Stanovick, J., Mahecha, M.D., Reichstein, M., Detto, M., Law, B.E., Wohlfahrt, G., Arriga, N., Campos, J., McCaughey, J.H., Montagnani, L., Sevanto, K.T.P.U.S., Williams, M., 2009. Biosphere-atmosphere exchange of $\mathrm{CO}_{2}$ in relation to climate: a cross-biome analysis across multiple time scales. Biogeosciences $6(10)$, 2297-2312.

Swenson, N.G., Enquist, B.J., Pither, J., Kerkhoff, A.], Boyle, B., Weiser, M.D., Elser, J.J., Fagan, W.F., Forero-Montana, J., Fyllas, N., Kraft, N.J.B., Lake, J.K., Moles, A.T. Patino, S., Phillips, O.L., Price, C.A., Reich, P.B., Quesada, C.A., Stegen, J.C. Valencia, R., Wright, I.J., Wright, S.J., Andelman, S., Jorgensen, P.M., Lacher, T.E. Monteagudo, A., Nunez-Vargas, M.P., Vasquez-Martinez, R., Nolting, K.M., 2012. The biogeography and filtering of woody plant functional diversity in North and South America. Global Ecol. Biogeogr. 21 (8), 798-808.

Tsui, O.W., Coops, N.C., Wulder, M.A., Marshall, P.L., 2013. Integrating airborne LiDAR and space-borne radar via multivariate kriging to estimate above-ground biomass. Remote Sens. Environ. 139, 340-352.

Urbanski, S., Barford, C., Wofsy, S., Kucharik, C., Pyle, E., Budney. J., McKain, K, Fitzjarrald, D., Czikowsky, M., Munger, J.W., 2007. Factors controlling CO2 exchange on timescales from hourly to decadal at Harvard Forest. J. Geophys. Res. Biogeosci. 112 (G2).

Ustin, S.L., 2013. Remote sensing of canopy chemistry. Proc. Nat. Acad. Sci. U. S. A. $110(3), 804-805$.

Ustin, S.L., Gamon, J.A., 2010, Remote sensing of plant functional types. New Phytol. $186(4), 795-816$.

Ustin, S.L., Roberts, D.A., Gamon, J.A., Asner, G.P., Green, R.O., 2004. Using imaging spectroscopy to study ecosystem processes and properties. Bioscience 54 (6), 523-534.

van Bodegom, P.M., Douma, J.C., Verheijen, L.M., 2014. A fully traits-based approach to modeling global vegetation distribution. Proc. Nat. Acad, Scl. U. S. A. 111 (38), 13733-13738.

van Bodegom, P.M., Douma, J.C., Witte, J.P.M., Ordonez, J.C., Bartholomeus, R.P., Aerts, R., 2012. Going beyond limitations of plant functional types when 
predicting global ecosystem-atmosphere fluxes: exploring the merits of traits-based approaches. Global Ecol. Biogeogr. 21 (6), 625-636.

van der Tol, C., Verhoef, W., Timmermans, J., Verhoef, A., Su, Z., 2009. An integrated model of soil-canopy spectral radiances, photosynthesis, fluorescence, temperature and energy balance. Biogeosciences 6 (12), 3109-3129.

van Ommen Kloeke, A.E.E., Douma, J.C., Ordonez, J.C., Reich, P.B., van Bodegom, P.M. 2012. Global quantification of contrasting leaf life span strategies for deciduous and evergreen species in response to environmental conditions. Global Ecol, Biogeogr. 24 (2), 224-235.

Verheijen, L.M., Brovkin, V., Aerts, R., Bonisch, G., Cornelissen, J.H.C., Kattge, J. Reich, P.B., Wright, I.J., van Bodegom, P.M., 2013. Impacts of trait variation through observed trait-climate relationships on performance of an Earth AT model: a conceptual analysis. Biogeosciences $10(8)$, 5497-5515.

Violle, C., Enquist, B.J., McGill, B.J., Jiang, L., Albert, C.H., Hulshof, C., Jung, V., Messier, J., 2012. The return of the variance: intraspecific variability in community ecology. Trends Ecol. Evol. 27 (4), 244-252.

Violle, C., Navas, M.L., Vile, D., Kazakou, E., Fortunel, C., Hummel, I., Garnier, E, 2007. Let the concept of trait be functionall Oikos 116 (5) 882-892.

Wall, D.H., Moore, J.C., 1999. Interactions underground - soil biodiversity, mutualism, and ecosystem processes. Bioscience $49(2), 109-117$.

Wang, Y.P., Lu, X.J., Wright, I.J., Dai, Y.J., Rayner, P.J., Reich, P.B., 2012. Correlations among leaf traits provide a significant constraint on the estimate of global gross primary production. Geophys. Res. Lett., 39.
Wardley, N.W., Curran, P.J., 1984. The estimation of green-leaf-area index from remotely sensed airborne multispectral scanner data. Int. J. Remote Sens. 5 (4), 671-679.

White, A., Cannell, M.G.R., Friend, A.D., 2000. The high-latitude terrestrial carbon sink: a model analysis. Global Change Biol, 6 (2), 227-245.

Willis, C.G., Halina, M., Lehman, C., Reich, P.B., Keen, A., McCarthy, S., Cavender-Bares, J., 2010. Phylogenetic community structure in Minnesota oak savanna is influenced by spatial extent and environmental variation. Ecography 33 (3), 565-577.

Wright, 1.J., Reich, P.B., Westoby, M., Ackerly, D.D., Baruch, Z., Bongers, F., Cavender-Bares, J., Chapin, T., Cornelissen, J.H.C., Diemer, M., Flexas, J., Garnier, E., Groom, P.K., Gulias, J., Hikosaka, K., Lamont, B.B., Lee, T., Lee, W., Lusk, C., Midgley, J.J., Navas, M.L., Niinemets, U., Oleksyn, J., Osada, N., Poorter, H., Poot, P., Prior, L., Pyankov, V.I., Roumet, C., Thomas, S.C., Tjoelker, M.G., Veneklaas, E.J, Villar, R., 2004. The worldwide leaf economics spectrum. Nature 428 (6985), 821-827.

Zarco-Tejada, P.J., Miller, J.R., Harron, J., Hu, B.X., Noland, T.L, Goel, N., Mohammed, G.H., Sampson, P., 2004. Needle chlorophyll content estimation through model inversion using hyperspectral data from boreal conifer forest canopies. Remote Sens. Environ. 89 (2), 189-199.

Zhang, Y.G., Guanter, L., Berry, J.A., Joiner, J., van der Tol, C., Huete, A., Gitelson, A., Voigt, M., Kohler, P., 2014, Estimation of vegetation photosynthetic capacity from space-based measurements of chlorophyll fluorescence for terrestrial biosphere models. Global Change Biol. 20 (12), 3727-3742. 